\title{
Contribution of the solar systems to the nZEB and ZEB design concept in Portugal - Energy, Economics and Environmental Life-cycle Analysis
}

\author{
Sandra Monteiro Silva ${ }^{1}$, Ricardo Mateus ${ }^{1}$, Luís Marques², Marta Ramos ${ }^{2}$ and Manuela \\ Almeida ${ }^{1}$ \\ 1 Centre for Territory, Environment and Construction (CTAC), University of Minho, \\ Campus de Azurém, 4800-058 Guimarães, Portugal; \\ 2 DepartamentolCentro de Física, University of Minho, Campus de Gualtar, 4710-057 \\ Braga, Portugal
}

\begin{abstract}
The recast of the Energy Performance of Buildings Directive settle that by 2020 all new buildings should reach nearly zero energy levels (2018 for buildings owned or occupied by public authorities). Therefore, technicians involved in the design, management and approval of buildings should be able to understand and apply nearly zero energy buildings (nZEB) concepts in both new buildings and refurbishment of existing ones. At European Union (EU) level there are differences in commitment to the EU targets and the construction of nZEB. Therefore, it is necessary to develop studies that demonstrate the advantages of the nZEB and ZEB design process that can increase the awareness of both building clients and other stakeholders regarding this issue. In this context, the aim of this paper is to assess the energy and environmental life-cycle performance of different renovation scenarios (Basic Renovation, nZEB and ZEB) for multifamily buildings in Portugal. This will be focused on the goals of the nZEB and ZEB design process and on the contribution of solar systems (both solar thermal collectors, STCs, and photovoltaic panels, PVs) to the achievement of those goals. The results presented in this paper show that, in the Portuguese climate and for a typical multi-family building, it is possible to overcome $100 \%$ of the energy needs for acclimatization and domestic hot water (DHW) preparation with the integration of solar systems. From the results, it is also possible to conclude that a significant amount of energy and carbon emissions are avoided for every renovation scenario during the considered lifetime (30 years) and that the nZEB and ZEB scenarios are cost-effective with attractive payback times.
\end{abstract}

\section{Introduction}

The recast of the Energy Performance of Buildings Directive [1] has ambitious goals for the building sector to reduce energy use as well as carbon emissions.

The reduction of energy consumption and carbon emissions are important goals for the European Union (EU) due to Europe's energy dependency, an increase of energy costs and climate change mitigation. The building sector is responsible for $40 \%$ of the total energy consumption and $32 \%$ of the carbon emissions in Europe [2]. Residential buildings represent $25 \%$ of the total energy consumption in Europe being an important target for policies aiming at improving the energy efficiency and reducing the carbon emissions [3].

The reduction of energy consumption and the use of energy from renewable sources in the buildings sector are important measures needed to reduce EU energy dependency and carbon emissions. The potential of emissions mitigation in this sector is relevant and as much as $80 \%$ of the operational costs of standard new buildings can be saved through integrated design principles, often at no (or little) extra cost over the lifetime of the measure [2]. 
Utilizing the full potential for energy savings within the European building sector can bring significant benefits: boosting the ailing European economy and increasing EU energy security.

Improving the buildings' energy performance is an important part of the EU 2020 and 2030 energy targets as well as of the roadmap for moving towards a competitive low carbon economy in $2050[1,4,5]$. The targets defined for 2020 are $20 \%$ reduction in energy consumption, $20 \%$ reduction in carbon emissions and $20 \%$ increase in renewable energy use [1]. The EU framework on climate and energy for 2030 is committed to reducing, until 2030, EU domestic carbon emissions by $40 \%$ when compared with the 1990 level and $25 \%$ reduction in energy consumption [5]. This target will ensure that EU is on the cost-effective track towards meeting its objective of cutting emissions by at least $80 \%$ by 2050 [4]. The Commission also proposes an objective of increasing the share of renewable energy to at least $27 \%$ of the EU's energy consumption by 2030 [5].

The EU legislative framework has been significantly strengthened by the recast of the Energy Performance of Buildings Directive (EPBD-recast, 2010/31/EU) and by the Renewable Energy Directive (RED, 2009/28/EC) [1,6]. Both Directives set conditions for moving towards nearly zero energy buildings (nZEB) by 2020.

According to the EPBD-recast, all EU Member States shall ensure that by 31 December 2020 all new buildings are nearly Zero Energy Buildings (nZEB) and after 31 December 2018 new buildings occupied and owned by public authorities are nearly zero energy buildings [1].

This Directive defines nZEB as a building that has a very high energy performance and requires the calculation of primary energy indicator. The nearly zero or very low amount of energy required should be covered to a very significant extent by energy from renewable sources, including energy from renewable sources produced on-site or nearby.

The EPBD-recast also requires that buildings have to be cost-effective during their life cycle and establishes a methodology for cost optimal calculations. This methodology is intended to guide member states in the process of establishing minimum energy requirements for buildings and building components $[2,3,7,8]$.

To achieve the settled targets, it is also mandatory to improve the performance of the existing building stock due to its representativeness in the overall building stock and poor energy performance. Additionally, the small rate of new building construction in Europe (1-2\% per year) makes energy savings insignificant if the focus is only on new building construction [9]. Renovation towards nZEB is now a goal of the European countries. The renovation of existing buildings is an opportunity to improve their energy performance that is many times missed. This is due to high investment costs and also to lack of know-how and awareness (from owners, tenants and other stakeholders) regarding the cost-effectiveness of the energy retrofit measures [10], especially if a life cycle cost approach is considered and ancillary benefits of energy retrofit measures are taken into account. Ancillary benefits of retrofit measures beyond energy savings include lower noise levels and improved comfort from insulation and glazing, better indoor air quality and temperature control from new HVAC systems, less operational maintenance or increased energy security against energy price fluctuations by the deployment of renewable energy resources [2].

The nZEB performance is achieved by: reducing the buildings' energy needs, through passive approaches (e.g. improving insulation levels, optimizing solar gains and using external shading systems and night cooling); selecting efficient appliances and systems (e.g. lighting, heating, cooling and ventilation systems); and on-site production of renewable energy to reduce the remaining non-renewable energy use. Solar thermal and photovoltaic systems together with biomass and geothermal energy sources are the most common energy sources used in buildings. In buildings, especially in building renovation, solar thermal and photovoltaic systems can be easily added or integrated into facades and/or roofs and therefore show a greater potential to be used as renewable energy systems than other systems [11]. 
Buildings require energy both in the form of heat (e.g. for the domestic hot water preparation, space heating and even space cooling) and electricity (e.g. for lighting, electric appliances, heating and cooling). Therefore, solar thermal (STC), photovoltaic (PV) and hybrid photovoltaic-thermal (PVT) systems are necessary technologies for building applications since they can be used to replace non-renewable energy systems in proving renewable heat, electricity and cooling energy sources.

The energy produced by an STC system can be transferred to a hot water storage tank, to a swimming pool, or can be used to heat air in the building. It can also be used for cooling the building when using an adsorption chiller (more common in office buildings that have higher cooling needs). Solar thermal energy can be stored for short periods (for DHW) or be used with thermal storage (for example phase change materials - PCM) for seasonal storage.

PV systems are more expensive and are less efficient than STC, being the initial costs a major barrier to the installation of these systems buildings [12-14]. Among other factors, when installing this type of system, it is important to evaluate the resource potential (e.g. incident solar radiation and the number of hours of sun) and the cost of electricity (i.e. higher energy prices make solar PV technology more affordable) [13]. The availability of incentives (e.g. grants or rebates) and the possibility to sell renewable energy generated in excess on site to the public electricity network also influences the cost effectiveness of these systems. Solar electricity has to be used as it is produced or can be stored in batteries that are expensive.

Compared to other renewable energy systems, STC, PV and PVT systems are, in general, more easily integrated into buildings (e.g. both flat or pitched roofs or facades), are more reliable and have lower maintenance costs (e.g. most manufacturers give a 20-25 years lifetime warranty) [15]. As an example and compared with wind turbines, they are more easily integrated into the building aesthetics, do not produce noise and do not have impact on birds. These systems are also easier to install than ground source heat pumps, which require the use of buried ground pipes whose feasibility and efficiency depends on the space availability and geology of the site.

The main disadvantages of solar energy are the initial cost of the systems, the intermittency and unpredictability, availability of sunlight during daytime only and the dependence on the local climate conditions [16]. Although solar energy can still be collected during cloudy and rainy days, the efficiency of the solar systems is reduced.

The installation of solar systems requires a significant amount of space and some roofs are not large enough to fit the number of solar panels that are needed to meet the building energy needs (thermal and electricity) and the installation on the facades can be limited due to shading produced by surrounding buildings. The use of PVT solar systems can simultaneously provide electricity and heat, needing less space and achieving a higher conversion rate of the absorbed solar radiation than standard PV modules [17].

In the feasibility studies regarding the benefits of using solar systems, it is also necessary to consider the potential environmental impacts related to their manufacture, transportation and maintenance and the environmental benefits related to the energy savings [15].

The challenge is thus to develop and select cost-effective strategies for increased efficiency and deployment of renewable energy to achieve the best building performance (e.g. less energy use, fewer carbon emissions and higher co-benefits related with indoor environmental quality) at the lowest possible effort (e.g. initial costs, life cycle costs and occupant's disturbance in the case of building renovation).

In building retrofit, meeting nearly zero energy targets mainly by reducing the energy demand by increasing the energy performance of the building envelope can be a challenging process. For instance, taking costs into consideration, cost optimality is often achieved at levels far from nearly zero energy levels [2]. From there it is often more cost-effective to use renewable energy sources (if economically available) than to strive for reducing energy demand. At the same time, in many cases, the use of renewable energy sources is not only cost-effective but also 
leads to significant reductions in emissions and in non-renewable energy consumption, even if the effects on total primary energy use are small.

Since the EPBD-recast does not define the targets for the nZEB and ZEB building design, each Member State must develop specific studies and methodology to define these energy standards. These studies must take into consideration the local context, for instance, at the level of the following aspects: climate, construction technologies, energy performance of the existing building stock, sociocultural characteristics of the building occupants, economic constraints and energy mix.

The assessment of the life-cycle performance of a renovation scenario can be based on several indicators, such as cost, operational energy consumption or environmental impacts of building materials and energy consumption. Whatever the indicators used the generic pattern of its time evolution and payback time can be schematised as shown in Figure 1.

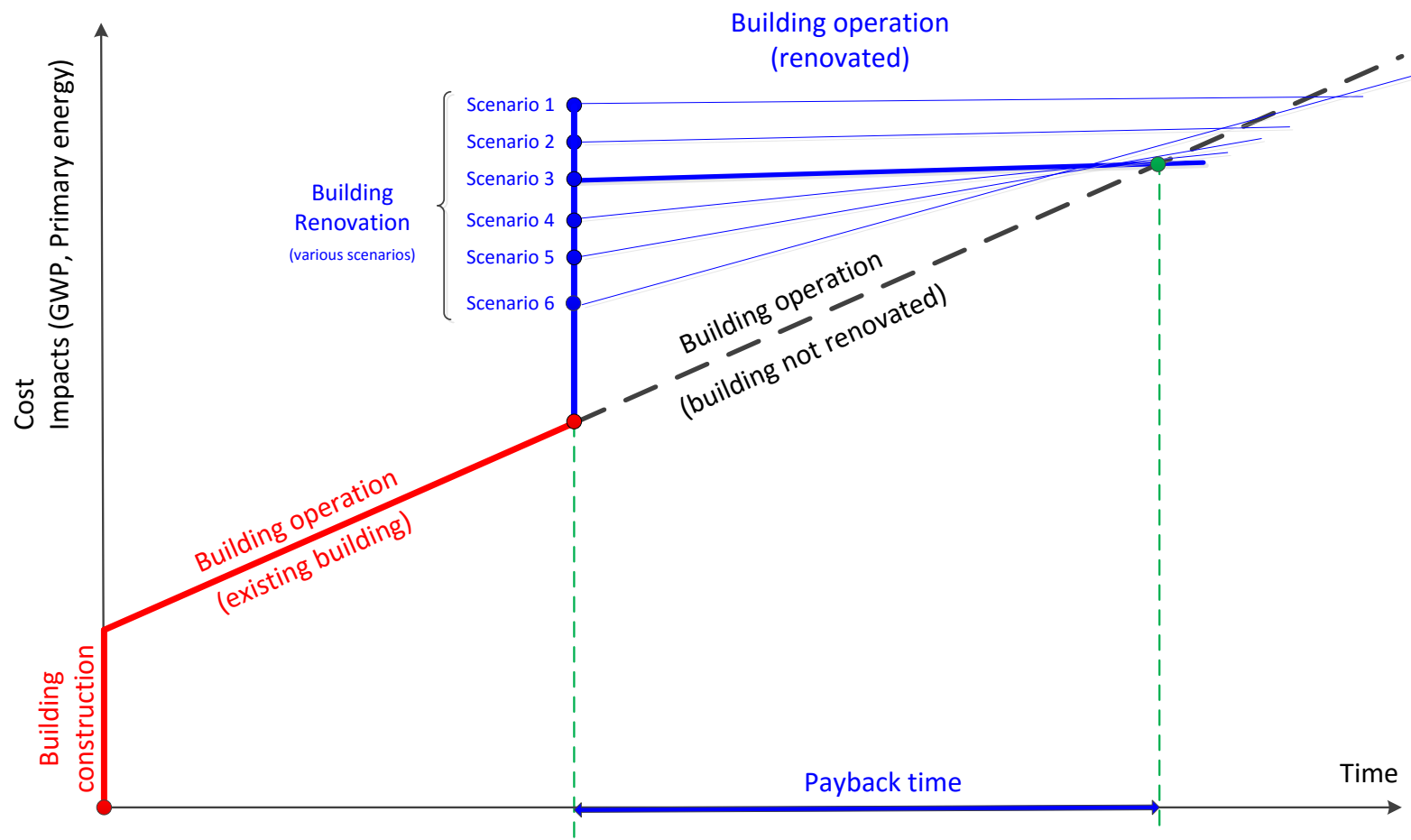

Figure 1 - Schematic representation of the payback time of renovation operations [21]

Nevertheless, recent studies (e.g. [15,18]) concluded that most assessments are not based on a comprehensive LCA methodology, since they are only focused on a small number of environmental indicators. The reasoning for this is the simplification of the LCA method for practical use, considering only the indicators that express the commitment of the building design with the EU energy targets. Two popular indicators generally used to assess and compare the environmental life-cycle performance both at buildings and energy systems level are the energy payback time (EPBT) and carbon emissions payback time (GPBT). Other studies state that there is a lack of findings based on the use of comprehensive life-cycle analysis methods to assess the benefits of using solar systems (e.g. [19]).

Across Europe, several studies are being developed to define these high-performance energy standards. These studies are being carried out using real case studies or prototypes, focusing the cost effectiveness of different design scenarios for both new and renovated building. The design scenarios include passive or active design approaches, using or not renewable energy sources. Morelli et al. [20] studied the renovation of a Danish multi-family building built in 1896 and concluded that it is hard to attain a nearly zero energy building without using renewable energy sources. However, authors also found that through the implementation of passive retrofit measures (e. g. insulation and new windows), the energy use can be significantly reduced when compared to the energy use before the renovation [20]. It also concluded that 
new technologies are needed to attain the reduction in energy use required to meet the nearly zero level when renovating buildings [20].

Badea et al. [14] performed a life cycle cost of different types of energy retrofitting solutions applied to buildings. For the climatic context of Bucharest, this study found that the additional investment in an energy efficient house can be recovered in 16-26 years, 9-16 years and 1628 years if the replaced HVAC system is classical gas fuelled, electric or district distribution [14]. Additionally, it also highlighted the importance of energy cost in the feasibility of using renewable energy systems, mainly the PV systems.

In Portugal, studies to set the nZEB and ZEB standards are still on-going [3]. The energy context in Portugal shows that the residential sector is a major consumer of energy, consuming around $20 \%$ of the total primary energy consumption and about $25 \%$ of it is used for the preparation of domestic hot waters (DHW), $22 \%$ for space heating and $1 \%$ for space cooling [22].

In this context, the aim of this paper is to analyse and compare the life-cycle performance of three energy renovation scenarios (Basic, nearly Zero Energy Building - nNEB and Zero Energy Building - ZEB) for a Portuguese residential building and to compare it with the existing building (Before Renovation) scenario. The Basic scenario corresponds to the adoption of energy renovation principles that meet the minimum energy requirements of the Portuguese thermal regulation [23]. The nZEB corresponds to a cost-optimal renovation scenario, according to the methodology of the EPBD recast [1]. For Portugal this means a renovation scenario with around $80 \%$ energy savings compared with a scenario that fulfils the minimum energy requirements [7]. The Zero Energy Building is a scenario where the non-renewable energy used in the nearly zero energy building for HVAC and DHW is compensated by the onsite harvested energy from renewables. The analysis is focused on the contribution of the solar systems in the increased costs and environmental impacts during the renovation works and its reduction during the operation phase.

For this study, a typical Portuguese multifamily building was chosen. The building is representative of the Portuguese multifamily housing stock built between 1990 and 2000, and represents $41 \%$ of the total Portuguese multifamily housing stock [24].

This study is in the continuation of previously developed studies $[3,7]$ where the cost-optimal renovation scenarios for Portuguese building where studied. These studies where focused on studying the cost and energy implications of different renovation scenarios and this research broadens the scope by including the analysis of the environmental life-cycle performance. This analysis is aimed at presenting, together with the cost and energy analysis, the environment life-cycle burdens resulting from different renovation scenarios. To overcome this goal, the study is based on the analysis of the: i) life-cycle impacts resulting from each scenario, using a standardized LCA method; ii) energy payback time (EPBT); and carbon emissions payback time (GPBT).

\section{Methodology}

\subsection{Analysis considerations}

The analysis and comparison of the renovation scenarios were based on the following indicators:

1 - Annual Primary Energy consumption;

2 - Environmental impact assessment indicators, according to EN 15978:2011 [25] methodology;

3 - Cumulative energy demand during the studied lifetime (30 years);

4 - Cumulative lifetime costs (30 years);

5 - Economic payback time (EPBT); 


\section{6 - Greenhouse emissions payback time (GPBT).}

The methodology was applied both at the whole building and energy systems level.

\subsection{Assessment of energy needs and costs}

The calculations of the energy needs followed the methodology of the Portuguese regulation for the thermal performance of residential buildings [23] which is based on the quasi-steady state method presented in ISO 13790 [26]. The Portuguese thermal regulation provides the values of the degree-days and uses the envelope heat balance method for the calculation of heating needs. With regard to cooling needs, it uses the average difference between indooroutdoor temperature and the envelope heat balance during the cooling period. The energy used for Domestic Hot Water preparation is calculated according to the reference DHW consumption: 40 litres per person and per day, heated at $60^{\circ} \mathrm{C}$. In the methodology the internal load for people, lighting, appliances and equipment considered is $4 \mathrm{~W} / \mathrm{m}^{2}$. The energy necessary for lighting and appliances is not accounted for in this methodology.

The primary energy was calculated considering the conversion factors of $2.5 \mathrm{kWhPE} / \mathrm{kWh}$ for electricity and $1 \mathrm{kWhPE} / \mathrm{kWh}$ for natural gas, biomass and thermal energy from solar systems. For the calculation of the non-renewable primary energy, the contribution of the on-site renewable energy systems (solar thermal, photovoltaic) is deducted from the total amount of primary energy use, which is according to Portuguese regulation. In the results, average values per $\mathrm{m}^{2}$ refer to the acclimatized net floor area.

The indoor comfort conditions considered were an absolute minimum of $18^{\circ} \mathrm{C}$ for air temperature in winter and an absolute maximum of $25^{\circ} \mathrm{C}$ for air temperature and $50 \%$ for relative humidity in summer, in accordance with the Portuguese thermal performance of residential buildings regulation [23].

The costs of the renovation scenarios and the related maintenance costs were estimated based on market surveys. The energy costs are based on Portuguese energy prices and the estimation of the evolution of the energy prices for the calculation period follows the scenario given by EC [27]. The average prices of energy (VAT included) considered were $0.22 € / \mathrm{kWh}$ for the electricity and $0.08 € / \mathrm{kWh}$ for natural gas.

The global costs of each of the retrofit scenarios defined earlier refer to the net present value (NPV) of the capital costs for the initial retrofit works and replacements during the considered period of 30 years, the maintenance costs and the energy costs, with a discount rate of $3 \%$.

Following this method, calculations were performed for the different retrofit scenarios. After these calculations, the required contribution from PV energy was calculated to reach the zero energy level. The solar thermal contribution was performed using Soltem that is a software application that simulates and analyses the performance of solar systems, tuned to the specific climate and technical environment prevalent in Portugal. The PV contribution is based on the EC's Photovoltaic Geographical Information System (PVGIS) and the location (Porto, 41.18N, 8.68E) to determine PV efficiency and output.

To determine the costs and the cost savings was considered a lifecycle cost approach for the global cost during the lifetime of the initial investments of the renovations scenarios. This is in accordance with the EPBD requirements [1]. Besides comprehensive investment costs, also comprehensive economic net benefits have to be determined. The latter can be savings of energy costs, operational costs and maintenance costs as well as revenues from on-site generated energy exports to a grid.

Besides the actual situation, three renovation scenarios were considered for the study:

- Before the renovation (existing situation): reference case for base level to get the reference of the reduction of energy use. This corresponds to the maintenance scenario; 
- Basic renovation, to fulfil the current national thermal regulation (minimal requirements renovation);

- National nZEB (nearly Zero Energy Building) requirements, that corresponds to the cost optimal retrofit and is equivalent to a reduction of the primary energy consumption of about $80 \%$ when compared with the original consumption before renovation;

- ZEB (Zero Energy Building = the net use of primary energy on annual basis = $\left.0 \mathrm{kWh} /\left(\mathrm{m}^{2} \mathrm{a}\right)\right)$ requirements for space heating and cooling, ventilation, and domestic hot water production.

The existing situation, maintenance scenario, and the basic renovation serves as reference situation for determining and assessing the impacts of an energy related renovation solution on energy use, carbon emissions, materials, costs and possible benefits.

In all the renovation scenarios, materials, workmanship and maintenance costs were considered (Table 1). The life span and the annual preventive maintenance including operation, repair and servicing costs in \% of the initial investment of the systems defined in the EN 15459:2007 standard were considered. The radiators, fan coils, gas heater, HVAC systems and solar thermal systems were replaced after 20 years and the PV system after 25 years (in accordance with manufacturers' warranties).

Table 1 - Cost $(€)$ of the different renovation scenarios

\begin{tabular}{|c|c|c|c|c|}
\hline Costs $[€]$ & $\begin{array}{c}\text { Before } \\
\text { renovation/maintenance }\end{array}$ & Basic renovation & nZEB renovation & ZEB renovation \\
\hline \multicolumn{5}{|l|}{ Envelope } \\
\hline Facade & 58138 & 108860 & 109874 & 109874 \\
\hline Roof & 38851 & 40981 & 42259 & 42259 \\
\hline Garage ceiling & - & 3408 & 7242 & 7242 \\
\hline Windows & - & 31296 & 27552 & 27552 \\
\hline \multicolumn{5}{|l|}{ Systems } \\
\hline Space heating & 18382 & 22500 & 192285 & 192285 \\
\hline Space cooling & 77994 & 95085 & 95085 & 95085 \\
\hline Gas heater & 11502 & 11502 & 11502 & 11502 \\
\hline \multicolumn{5}{|c|}{ Renewable energy systems } \\
\hline Solar thermal collectors & - & 26280 & 41782 & 41782 \\
\hline PV system & - & - & - & 57140 \\
\hline Renovation total & 204867 & 339912 & 527581 & 584721 \\
\hline
\end{tabular}

The costs considered in the maintenance scenario are the reparation of cracks and the cleaning and painting of the facade and the replacement of the roof tiles (removal of the tiles and transport to landfill and installation of the new roof tiles). Additionally, the radiators and fan coils and the gas heater were also replaced for equivalent ones.

In the basic renovation, the costs considered are the cost of the materials and workmanship of the renovation works (repair of cracks, cleaning the facade, application of the ETICS on the façade, application of the insulation on the roof and garage's ceiling, replacement of the roof tiles and of the windows) and the systems and fittings (radiators, cooling system, gas heater, storage tank and solar thermal collectors).

In the nZEB and ZEB renovation, the costs considered are the cost of the materials and workmanship of the renovation works (repair of cracks, cleaning the facade, application of the ETICS on the façade, application the insulation on the roof and garage's ceiling, replacement of the windows and roof tiles) and the systems and fittings (gas heater, HVAC systems for heating and for cooling, storage tank and solar thermal collectors). Additionally, the ZEB scenario includes the costs of the PV system. 


\subsection{Environmental Life-cycle assessment}

The methodology used for environmental life-cycle analysis (LCA) is based in the EN 15978:2011 [28] and follows the steps of the EN ISO 14044:2006 [29]. LCA is essentially an iterative process that includes the following major stages: i) Goal and Scope Definition; ii) Life Cycle Inventory (LCI); Life Cycle Impact Analysis (LCIA) and interpretation of the results. In the first stage, the purpose of the work, the audiences, the system boundaries (temporal, geographical and technological), the sources of data and the environmental impact categories to be used are identified. LCI stage includes collecting data for each unit process regarding all relevant inputs and outputs of energy and mass flow, as well as data on emissions to the air, land and water. This phase includes calculating both, the material and energy input and output of a building system. The LCIA phase evaluates potential environmental impacts. The purpose of this phase is to estimate the importance of all environmental burdens obtained in the LCI by analysing their influence on selected environmental loads. The interpretation may be described as the systematic procedure to identify, qualify, check, and evaluate the results of the LCl and LCIA stages. The main aim of interpretation is to analyse the results to the goals and scope and to formulate the conclusions that can be drawn from the LCA.

\subsubsection{Goal and scope}

The use of the LCA method is aimed at assessing the environmental impact of different rehabilitation scenarios. The declared unit used in this study is $1 \mathrm{~m}^{2}$ of net floor area of a renovated multifamily building that was designed to provide different levels of energy performance during 30 years: basic renovation, nZEB renovation and ZEB renovation. In the comparisons, an additional scenario (before renovation or maintenance scenario) is used as reference. The time boundary of this study is 30 years. Regarding the physical boundary, it includes the materials used for the construction elements and building technical systems (BTS) and the consumed energy, namely:

- Materials for construction elements and BTS components: only the materials added or replaced during the renovation stage are taken into account. The manufacturing, transportation to the building site and replacement of these materials are included in the calculation. The LCIA is influenced by the service life of the construction materials and the BTS's components. The BTS included are the ones used for cooling, heating and preparation of domestic hot water;

- Operational energy used: this includes the energy used by the considered BTS's to fulfil its requirement (heating, cooling and DHW production) during the building operation stage.

Further details regarding the physical boundaries are presented in the section bellow.

\subsubsection{System boundaries}

According to EN 15978:2011 [28], the system boundary determines the unit processes that are taken into account in assessment. In the case of this research, since the case study is an existing building, the system boundary shall include all stages representing the remaining service life and the end of life stage of the building. This standard recommends that the building life-cycle information is organized in the following stages: A1-3 - Product stage; A4-5 Construction Processes stage; B1-7 - Use stage; and C1-5 End-of-life stages. The boundaries, scenarios and considerations included in the cradle to grave analysis of each renovation scenario are (Table 2):

i) Product stage (A1-3):

- A1 - production/extraction of raw materials necessary to manufacture the building materials and building technical systems - BTS (STC's and PVs); 
- $\mathrm{A} 2$ - transport and storage of raw materials;

- A3 - manufacturing processes to produce the building materials, STC's and PVs;

ii) Construction Process Stage (A4-5):

- A4 - transportation of the building materials and BTS for an average distance of $50 \mathrm{~km}$, using a lightweight capacity road transportation vehicle;

- A5 - installation of the BTS in the building. The construction processes related with the installation of the building products used in the energy retrofitting of the building envelope were not considered, due to the lack of consistent data. This will not affect the comparison of results since the construction processes used in the different scenarios are similar.

iii) Use stage (B1-7):

- B1 - (excluded) flows resulting from the use of the building products and BTS are excluded since it is considered they will not release any harmful substances to the environment;

- B2 - lifetime maintenance of the building products and BTS used in each renovation. It is included the production and transportation of the components and ancillary products used for maintenance (e.g. all cleaning processes necessary to maintain the performance level of the STCs and PVs);

- B3 - repair of the BTS during the lifetime;

- B4 - replacement of the BTS components during the lifetime;

- B5 - refurbishment of the BTS systems. It is assumed that the lifetime of the STCs is 20 years and the lifetime of the PVs is 25 years and this module includes production, transportation and installation of the new BTS. The end-of-life of the replaced systems is also included;

- B6 - operational energy used for heating, cooling and auxiliary energy used for the preparation of the domestic hot water;

- B7 - (excluded) operational water used is excluded from the analysis since the renovation scenarios do not affect the performance of the building at this level.

iv) End of life stage:

- $\quad$ C1 - (excluded) de-construction and demolition processes are excluded from the analysis due to the lack of consistent data. It will have no impact in the comparison of results since these processes are similar in the different renovation scenarios;

- $\mathrm{C} 2$ - transportation of the building demolition wastes during and average distance of a $50 \mathrm{~km}$ to a waste sorting facility, using a lightweight capacity road transportation vehicle;

- C3 - waste processing;

- $\quad$ C4 - disposal of the inert waste to landfill.

Besides the presented building life cycle information, according to EN 15978:2011 [28] other supplementary information beyond the building life cycle can be included (module D). For this reason, the benefits resulting from the electricity exported beyond the system boundaries of this study is included in the assessment.

\subsubsection{Life-cycle inventory}

The life-cycle inventory entails the quantification of the flows for and from a product system. In traditional life-cycle environmental analysis, the inventory flows include inputs of water, energy and raw materials, and releases to air, land and water. Taking into consideration the aims of 
this approach, the production and final destination of waste should also be included in the inventory.

This phase is very time consuming, since it is often necessary to collect, from the companies, data associated with the production system. However, approximately $80 \%$ of the data that is needed for a common LCA analysis is already published [30].

One of the sources of information more accepted by the experts in LCA is the Ecoinvent database [31]. The latest version available of Ecoinvent (v3.1) contains life-cycle inventory data for over 4000 industrial processes, including energy supply, resource extraction, materials supply, chemicals, metals, waste management systems and transport services. Gabi datasets [32] are another important source of average LCl data that is used in LCIA, namely at the European scale.

Besides the common building products, Ecoinvent datasets include average $\mathrm{LCl}$ data about solar thermal collectors and PVs, namely at the level of building-added systems and components. An analysis regarding the available LCl data related with solar systems can be found in the publication of Lamnatou et al. [15].

For this study, background data related with the considered process units was taken from the Ecoinvent 3.1 [31] LCl database. Regarding the solar thermal collectors, this database includes, for several types of solar collectors and systems, the production (i.e. materials, heat exchange fluid, copper pipes used in the installation of the system, water and energy used during production), delivery of the system parts with a van, mounting processes in the roof and disposal, but excludes auxiliary heating. The used values are not from a specific installation or from a specific building-added STCs producer, but are based on the average LCI of the collectors and complete systems sold in Switzerland during a year and therefore they intended to represent the average technology that is currently available on the market. Although the context of the LCl data is Switzerland, since there are only slightly differences between the technologies used within the European countries it is possible to assume that these figures are valid at the European scale.

Regarding PV systems, the Ecoinvent comprises LCl data for both the embodied impacts and the impacts resulting from the operation, i.e. production of electricity in these systems. The functional unit used in the LCl database is an installation of a capacity of $3 \mathrm{kWp}$ and a lifetime of 30 years for the context of Switzerland. In the case of the embodied impacts, data includes all components for the installation of a $3 \mathrm{kWp} \mathrm{PV} \mathrm{system,} \mathrm{including} \mathrm{the} \mathrm{impacts} \mathrm{resulting} \mathrm{from}$ the use of different types of cells, energy use for the mounting, transport of materials and workers to the construction site and disposal of components after end of life. In what concerns to the inventory related to the consumed energy, processes included in the Ecoinvent database [31] for each energy carrier appropriately represent the reality of most European countries, including Portugal, and include the interdependent network between countries that characterises the international trade in electricity [33]. This database presents the specific processes that correspond to the national electricity supply for low voltage consumers (electricity, low voltage (PT), market for, S), based on the energy mix of 2008.

In the energy calculations an annual output loss of 0.64 was considered for the PV panel's lifetime reduction of efficiency. This figure is recommend by the US National Renewable Energy Laboratory (NREL) for post year 2000 installed polycrystalline silicon (poly-Si) panels [34].

Regarding the life-cycle inventory of the different renovation scenarios, Table 2 presents the considered flows from and to the system in analysis in this study. Flows are assigned to the information modules of the building life cycle, according to the framework presented in EN15978:2011 [28]. 
Table 2 - Inventory flows considered in the life-cycle inventory of each scenario

\begin{tabular}{|c|c|c|}
\hline $\begin{array}{l}\text { Building life- } \\
\text { cycle Stage }\end{array}$ & Scenario & Considered flows \\
\hline \multirow{4}{*}{$\begin{array}{l}\text { Product } \\
\text { stage } \\
\text { (modules } \\
\text { A1-3) }\end{array}$} & $\begin{array}{l}\text { Before renovation/ } \\
\text { maintenance }\end{array}$ & $\begin{array}{l}\text { The cradle-to-gate flows of the following building products/energy systems were included: } \\
\text { - Paint used in the external walls. }\end{array}$ \\
\hline & Basic renovation & $\begin{array}{l}\text { The same as the before renovation /maintenance scenario plus: } \\
\text { - External Thermal Insulation Composite System (ETICS) on the external walls }(3 \mathrm{~cm} \text { thick } \\
\text { expanded polystyrene (EPS) }-20 \mathrm{~kg} / \mathrm{m}^{3} \text { insulation layer + synthetic mortar + new external } \\
\text { aluminum sills in the windows); } \\
\text { - New aluminum windows with double-glazing; } \\
-5 \mathrm{~cm} \text { of mineral wool (MW) }-40 \mathrm{~kg} / \mathrm{m}^{3} \text { on the roof; } \\
-2 \mathrm{~cm} \text { of EPS }-17,5 \mathrm{~kg} / \mathrm{m}^{3} \text { under the first floor; } \\
\text { - Solar Thermal Collector (STC) system, covering } 60 \% \text { of the Domestic Hot Water (DHW) } \\
\text { needs. }\end{array}$ \\
\hline & nZEB renovation & $\begin{array}{l}\text { The same as the before renovation/maintenance plus: } \\
\text { - External Thermal Insulation Composite System (ETICS) on the external walls }(4 \mathrm{~cm} \text { thick } \\
\text { expanded polystyrene (EPS) - } 20 \mathrm{~kg} / \mathrm{m}^{3} \text { insulation layer + synthetic mortar + new external } \\
\text { aluminum sills in the windows); } \\
\text { - New PVC windows with double-glazing; } \\
-9 \mathrm{~cm} \text { of mineral wool (MW) }-40 \mathrm{~kg} / \mathrm{m}^{3} \text { on the roof; } \\
\text { - } 9 \mathrm{~cm} \text { of EPS on the first floor; } \\
\text { - Solar Thermal Collector (STC) system, covering } 60 \% \text { of the Domestic Hot Water (DHW) } \\
\text { needs. }\end{array}$ \\
\hline & ZEB renovation & $\begin{array}{l}\text { The same as the nZEB renovation plus: } \\
\text { - Photovoltaic (PV) system, covering } 100 \% \text { of remaining energy delivered for heating, } \\
\text { cooling and DHW preparation. }\end{array}$ \\
\hline \multirow{4}{*}{$\begin{array}{l}\text { Construction } \\
\text { process (A4- } \\
\text { 5) }\end{array}$} & $\begin{array}{l}\text { Before renovation/ } \\
\text { maintenance }\end{array}$ & Transportation of the building materials between the factory and the building for $50 \mathrm{~km}$. \\
\hline & Basic renovation & $\begin{array}{l}\text { Flows related with the transportation of the STC system during } 50 \mathrm{~km} \text { and its installation in } \\
\text { the building. }\end{array}$ \\
\hline & nZEB renovation & Transportation of the STC system during $50 \mathrm{~km}$ and its installation in the building. \\
\hline & ZEB renovation & $\begin{array}{l}\text { Transportation of the STC and PV systems during } 50 \mathrm{~km} \text { and their installation in the } \\
\text { building. Flows related with the installation works of both the STC and PV systems. }\end{array}$ \\
\hline \multirow[t]{4}{*}{$\begin{array}{l}\text { Use stage } \\
\text { (B1-7) }\end{array}$} & $\begin{array}{l}\text { Before renovation/ } \\
\text { maintenance }\end{array}$ & $\begin{array}{l}\text { The flows related with the following building products/energy systems were included: } \\
\text { - Operational delivered energy needs for heating, cooling and DHW preparation (in the } \\
\text { electricity, the Portuguese energy mix was considered); } \\
\text { - Paint used in the external walls (façades are painted every } 10 \text { years); } \\
\text { - Transportation of the paint during } 50 \mathrm{~km} \text {. }\end{array}$ \\
\hline & Basic renovation & $\begin{array}{l}\text { The same as the before renovation/maintenance scenario plus: } \\
\text { - Operational energy to operate the STCs. } \\
\text { - Products used in the maintenance of the STCs (e.g. thermal fluid replacement); } \\
\text { - Replacement of the Solar Thermal Collector (STC) system, covering } 60 \% \text { of the Domestic } \\
\text { Hot Water (DHW) needs (system is replaced in year 20); } \\
\text { - Transportation of the STC system during } 50 \mathrm{~km} \text {. }\end{array}$ \\
\hline & nZEB renovation & $\begin{array}{l}\text { The same as the before renovation /maintenance plus: } \\
\text { - Operational energy to operate the STCs; } \\
\text { - Products used in the maintenance of the STCs; } \\
\text { - Replacement of the Solar Thermal Collector (STC) system, covering } 100 \% \text { of the } \\
\text { Domestic Hot Water (DHW) needs (system is replaced in year 20); } \\
\text { - Transportation of the STC system during } 50 \mathrm{~km} \text {, }\end{array}$ \\
\hline & ZEB renovation & $\begin{array}{l}\text { The same as the nZEB renovation plus: } \\
\text { - Maintenance of Photovoltaic (PV) system (e.g. replacement of the DC/AC converters); } \\
\text { - Replacement of the Photovoltaic (PV) system, covering } 100 \% \text { of remaining energy } \\
\text { delivered for heating, cooling and DHW preparation (system is replaced in year 25). } \\
\text { - Transportation of the PV system during } 50 \mathrm{~km} \text {, }\end{array}$ \\
\hline \multirow[t]{4}{*}{$\begin{array}{l}\text { End-of-life } \\
\text { stage (C1-4) }\end{array}$} & $\begin{array}{l}\text { Before renovation/ } \\
\text { maintenance }\end{array}$ & $\begin{array}{l}\text { A scenario considering the flows related with: } \\
\text { - The transportation of the demolition wastes to a waste sorting facility during an average } \\
\text { distance of } 50 \mathrm{~km} \text {; } \\
\text { - Treatment of the inert wastes to landfill. }\end{array}$ \\
\hline & Basic renovation & The same scenario as the before renovation. \\
\hline & nZEB renovation & The same scenario as the before renovation. \\
\hline & ZEB renovation & The same scenario as the before renovation. \\
\hline \multirow{4}{*}{$\begin{array}{l}\text { Benefits and } \\
\text { loads } \\
\text { beyond the } \\
\text { system } \\
\text { boundary } \\
\text { (module D) }\end{array}$} & $\begin{array}{l}\text { Before renovation/ } \\
\text { maintenance }\end{array}$ & None. \\
\hline & Basic renovation & None. \\
\hline & nZEB renovation & None. \\
\hline & ZEB renovation & $\begin{array}{l}\text { The electricity produced by the PVs and exported to the external electricity network (the } \\
\text { annual output loss of the PV cells is considered in this calculation). }\end{array}$ \\
\hline
\end{tabular}




\subsubsection{Impact assessment}

The Environmental Impact Assessment Methods (EIAM) comprise the analysis of the input and output of materials, of energy consumption and of emissions to the environment of a product over its life cycle and therefore are based on the life-cycle inventory. According to EN15978:2011 [28] the results are expressed as indicators that represent the quantified environmental impacts and aspects caused by the building during its whole life cycle. This standard states that the assessment of the environmental performance of a building is based in 22 indicators, subdivided in the following four types: i) indicators describing environmental impacts (7 indicators); ii) indicators describing resource use (8); iii) indicators describing waste categories (3); and iv) indicators describing the output flows leaving the system (4).

Analysing the current state-of-art in the field of life-cycle analysis of design alternatives at the scale of buildings (e.g. [18,35]), building components (e.g. $[33,36])$ or building technical systems (e.g. $[15,37,38])$ it is possible to verify that for practicality most studies consider a limited set of indicators in the analysis rather than considering the complete list of the EN15804:2011 environmental indicators. As already concluded by other authors (e.g. [39,40]) commonly used environmental impact categories in this type of studies are global warming potential, acidification, ozone depletion and eutrophication.

Since this research is focused in the comparative analysis of the potential environmental impacts resulting from each energy-retrofitting scenario, only type 1 group of indicators of this standard were considered. According to the EN 15978:2011, the impact assessment should involve seven midpoint environmental impact categories, i.e. global warming, ozone depletion, acidification of soil and water, eutrophication, photochemical ozone creation and depletion of abiotic resources (elements and fossil, separately). Therefore, these were the impact categories considered in this study. These environmental impact categories were assessed using the characterization factors of the CML-IA life-cycle impact assessment method (developed in the Netherlands by the Institute of Environmental Sciences (CML) of Leiden University).

In addition to these indicators, two additional environmental categories are considered (Table 3). These categories are calculated based on a single issue method, the Cumulative Energy Demand (CED) [41]. This method expresses the depletion of energy resources based on the higher heating value and, in fact this provides the calculation of six environmental categories [42] (non-renewable, fossil; non-renewable, nuclear; non-renewable, biomass; renewable, biomass; renewable, wind, solar, geothermal; renewable, water) which were grouped and presented in a simplified form in only two categories with the same unit (megajoule-MJ): Nonrenewable Cumulative Energy Demand (CED NRE) and Total Cumulative Energy Demand (CED cycle energy consumption are of most importance in the comparison between different energy targets in building retrofit.

In order to facilitate the quantification process, a life-cycle analysis software (SimaPro 8.0.5) was used to modulate the life-cycle of the analysed renovation scenarios and to assess the abovementioned life-cycle impact categories.

The EIAM chosen in this study for the impact assessment of different renovation scenarios, including the impact categories, are the ones most used in LCA studies [43] and in the development of EPDs (Environmental Product Declarations), allowing the comparison of results for similar studies.

Table 3 presents the LCA method and the declared unit that was used to quantify the environmental indicators.

The EN15804:2011 standard does not present any methodology for the aggregation of the individual indicators presented above. The presentation of the performance at the level of each indicator is suitable for a business-to-business communication format, since it provides detailed information about the product or scenario under assessment. Nevertheless, several 
authors argue that a long list of parameters with their associated values is not useful to communicate the environmental performance of the real estate industry [18,44].

Table 3 - LCA method and declared unit that was used to quantify the environmental indicators

\begin{tabular}{|c|c|c|}
\hline Indicators & Units & Methods \\
\hline Global warming potential (GWP) & [Kg CO${ }_{2}$ equiv.] & CML-IA baseline (v3.02) \\
\hline Depletion of the stratospheric ozone layer (ODP) & [KgCFC-11 equiv.] & CML-IA baseline (v3.02) \\
\hline Acidification potential (AP) & [Kg SO${ }_{2}$ equiv.] & CML-IA baseline (v3.02) \\
\hline Eutrophication potential (EP) & [Kg PO 4 equiv.] & CML-IA baseline (v3.02) \\
\hline Formation potential of tropospheric ozone (POCP) & [Kg C $\mathrm{Kg}_{2} \mathrm{H}_{4}$ equiv.] & CML-IA baseline (v3.02) \\
\hline Abiotic depletion potential of fossil resources (ADP_FF) & [MJ equiv.] & CML-IA baseline (v3.02) \\
\hline Depletion of abiotic resources-elements (ADP elements) & [kg.SB equiv.] & CML-IA baseline (v3.02) \\
\hline Cumulative Energy Demand - non-renewable (CED $\left.{ }_{N R E}\right)$ & [MJ equiv.] & Cumulative Energy Demand (v1.09) \\
\hline Cumulative Energy Demand - total (CED TOTAL) & [MJ equiv.] & Cumulative Energy Demand (v1.09) \\
\hline
\end{tabular}

Therefore, in some studies the results are presented in the form of ratings or indexes to aid in evaluating building performance [45]. This means that different indicators are combined into global indicators, resulting in a quantitative aggregation of underlying indicators [44]. Aggregation typical involves the conversion of parameters into common units using a normalization method and the attribution of weights to each parameter according to its importance in the global performance [46]. Ratings or indexes thereby provide a simplified and comprehensive metric to evaluate and compare the impact the components and operations of a building have on the human beings and the natural environment [47].

The method used in this research aggregates all environmental indicators into a single index that presents the overall potential environmental performance improvement (Eli) of each renovation scenario. Consequently, the inclusion of a weighting system of environmental indicators is a necessary stage in this process.

For this purpose, the potential improvement of each renovation scenario is primarily assessed at the level of each environmental impact category. Then the overall potential environmental performance improvement $\left(E l_{i}\right)$ is estimated for each renovation scenario using the following Equation [1].

$E I_{i}(\%)=\frac{\sum_{j=1}^{n} \Delta E P_{j} \times w_{j}}{100}$

The $E l_{i}$ is the weighted improvement average of the environmental performance of each scenario $\mathrm{i}$, considering the improvement potential at the level of each indicator $\left(\triangle E P_{j}\right)$ and the weight of each indicator $\left(w_{j}\right)$. The sum of all weights must be equal to 1 . This assessment considers the default weights of the methodology MARS-SC [48] that are presented in Table 4 and therefore only covers the environmental impact categories considered in this methodology. In MARS-SC, the relative importance weight (\%) of each environmental impact indicator is based on the US Environmental Protection Agency's Science Advisory Board $(\mathrm{SAB})$ study $[49,50]$. At this level, it is worthwhile to mention that the used weighting system is based on value choices and therefore it presents the preferences or priorities of the group of stakeholders involved in the SAB study. This means that the weighted results (indexes) may be influenced by different opinions of other group of stakeholder. For better understanding of the obtained results, the results of the LCIA before the aggregation are also presented and a sensitivity analysis of the considered weighting system is carried out in the presentation of results.

Table 4 - Weight of each environmental indicator considered in the methodology MARS-SC [48]

\begin{tabular}{|l|l|}
\hline Indicator & Weight $-w_{j}(\%)$ \\
\hline GWP & 38 \\
\hline ODP & 12 \\
\hline AP & 12 \\
\hline EP & 12 \\
\hline POCP & 14 \\
\hline ADP_FF & 12 \\
\hline
\end{tabular}




\section{3 - Presentation of the Case Study}

The case study is a multifamily building located in the suburbs of Porto, Portugal. The building was chosen to be representative of the multifamily building stock: it reflects $41 \%$ of the multifamily building stock in Portugal [24] due to the climate zone where it is located, its geometry and energy performance. It was built in 1997. This type of building can be found around Portugal. It represents a typical building built between 1990 and 2000.

It is a multifamily building with its main facades oriented to the north-east and south-west (Figure 2). It has three floors, three entrances, with two apartments per floor and per entrance (Figure 2) and a half buried basement used as a garage. It has 18 apartments: nine two-bedroom dwellings (T2, with $60.69 \mathrm{~m}^{2}$ ) and nine three-bedroom dwellings (T3, with $80.86 \mathrm{~m}^{2}$ ). The building implantation area is $600 \mathrm{~m}^{2}$ and $1279 \mathrm{~m}^{2}$ of net area.

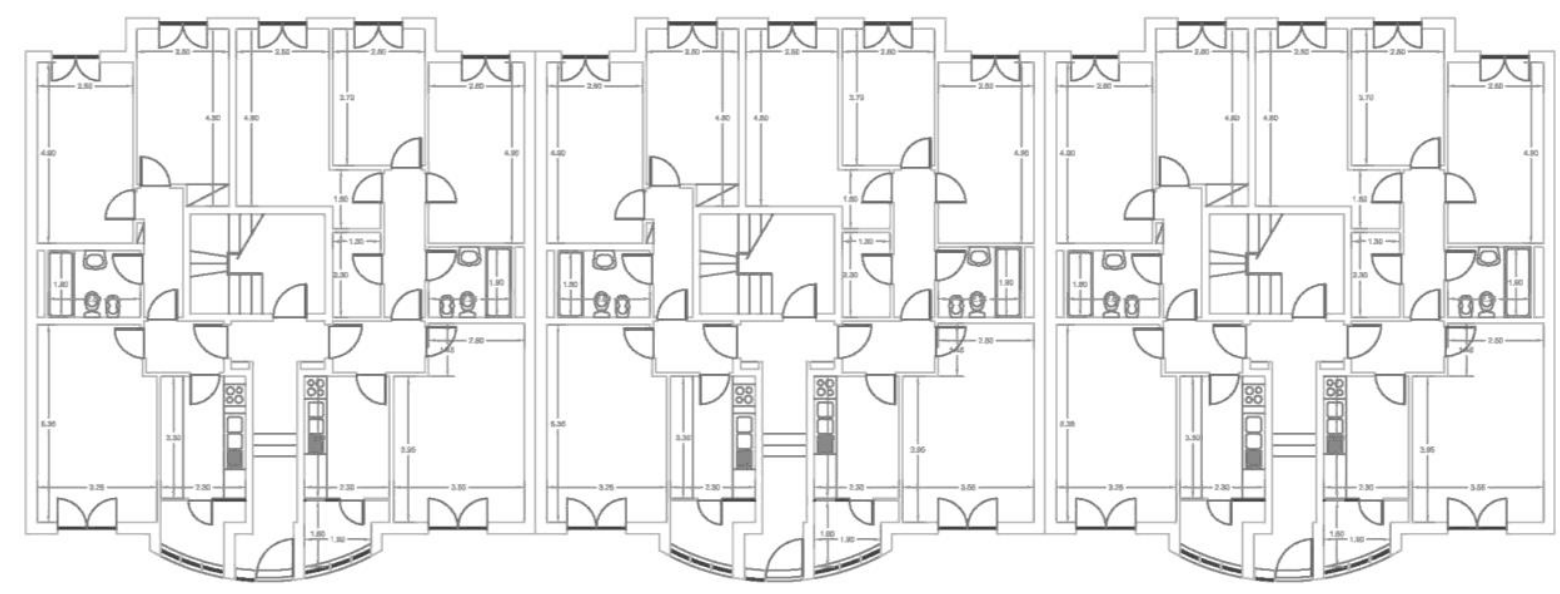

Figure 2 - First floor plan of the case study building

The building has a reinforced concrete structure and beam and pot slabs. There is no insulation in the building envelope, as it was the common practice at the time. The exterior walls are cavity wall construction (two masonry panes with an air gap, without thermal insulation) with render on the inside and outside surface; the windows are double glazed with aluminium frames; the floors are lightweight slabs; and the roof is pitched with ceramic roof tiles. The roof has $2 \mathrm{~cm}$ of mineral wool placed over the last slab and there is a $2 \mathrm{~cm}$ thick EPS insulation in the slab between the common garage (non-heated area) and the first floor.

Each apartment has a gas heater for DHW production (efficiency of 0.87 ) and there are no central heating or cooling systems, just portable electric heaters and fan coils, which is the common situation in this type of dwelling [24].

The properties of the building before and after each one of the renovation scenarios are shown in Table 5. Portuguese regulations define that the nZEB solution corresponds to the costoptimal renovation solution of the envelope.

The basic renovation scenario includes ETICS (External thermal insulation composite system) with a $3 \mathrm{~cm}$ thick layer of EPS (expanded polystyrene) on the exterior walls, with the application of $5 \mathrm{~cm}$ of MW (mineral wool) on the roof and $2 \mathrm{~cm}$ of EPS (in the slab between the common garage and the first floor), improved aluminium windows with double-glazing and the same gas heater with storage tank combined with solar panels for domestic hot water preparation. The solar thermal collectors were designed to cover around $60 \%$ of the DHW needs.

The nZEB renovation scenario includes ETICS with a $4 \mathrm{~cm}$ thick layer of EPS on the exterior walls, with $9 \mathrm{~cm}$ of MW on the roof, $9 \mathrm{~cm}$ of EPS on the slab between the common garage (non-heated area) and the first floor, PVC windows with double glazing and new gas heater 
with storage tank combined with solar panels for DHW preparation. In this scenario, the solar thermal collectors were designed to cover around $90 \%$ of the DHW needs.

The ZEB renovation scenario is the same as the nZEB in what concerns the envelope and systems (including DHW) with the installation of PV systems to cover the remaining energy needs.

Table 5 - Properties of the building before and after each of the renovation scenarios

\begin{tabular}{|c|c|c|c|c|}
\hline Properties of building & Before renovation & $\begin{array}{l}\text { After renovation, } \\
\text { Basic }\end{array}$ & $\begin{array}{c}\text { After renovation, } \\
\text { nZEB }\end{array}$ & $\begin{array}{c}\text { After renovation, } \\
\text { ZEB }\end{array}$ \\
\hline \multicolumn{5}{|l|}{ Thermal transmittance, $\mathrm{W} /\left(\mathrm{m}^{2} \cdot \mathrm{K}\right)$} \\
\hline$U_{\text {wall }}$ & 0.96 & 0.54 & 0.47 & 0.47 \\
\hline$U_{\text {roof }}$ & 1.01 & 0.45 & 0.31 & 0.31 \\
\hline$U_{\text {floor }}$ & 0.86 & 0.60 & 0.29 & 0.29 \\
\hline$U_{\text {window (glass/ frame) }}$ & 3.10 & 2.70 & 2.40 & 2.40 \\
\hline$U_{\text {door }}$ & 3.10 & 3.10 & 2.40 & 2.40 \\
\hline \multicolumn{5}{|l|}{ Linear thermal transmittance, $\mathrm{W} /(\mathrm{m} \cdot \mathrm{K})$} \\
\hline$\Psi_{\text {wall/wall }}$ & 0.55 & 0.50 & 0.50 & 0.50 \\
\hline$\Psi_{\text {root/wall }}$ & 1.00 & 1.00 & 1.00 & 1.00 \\
\hline$\Psi_{\text {floor/wall }}$ & 0.75 & 0.50 & 0.50 & 0.50 \\
\hline$\Psi_{\text {window/wall }}$ & 0.25 & 0.25 & 0.25 & 0.25 \\
\hline$\Psi_{\text {window/shutter box }}$ & 0.30 & 0.30 & 0.30 & 0.30 \\
\hline$\Psi_{\text {door/wall }}$ & 0.25 & 0.25 & 0.25 & 0.25 \\
\hline$\Psi_{\text {balcony/wall }}$ & - & - & - & - \\
\hline $\begin{array}{l}\text { Internal heat gains (heat from } \\
\text { inhabitants, appliances, equipment and } \\
\text { lighting) }\end{array}$ & \multicolumn{4}{|c|}{$4.0 \mathrm{~W} / \mathrm{m}^{2}$} \\
\hline Ventilation (air change rate) & 0.94 ach & 0.79 ach & $\begin{array}{l}\text { Winter: } 0.55 \text { ach } \\
\text { Summer: } 0.6 \text { ach }\end{array}$ & $\begin{array}{l}\text { Winter: } 0.55 \text { ach } \\
\text { Summer: } 0.6 \text { ach }\end{array}$ \\
\hline Heating system type and efficiency & Radiator (1.0) & Radiator (1.0) & HVAC (4.1) & HVAC (4.1) \\
\hline Cooling system type and efficiency & HVAC system (3.5) & HVAC system (3.5) & $\begin{array}{c}\text { HVAC system } \\
(3.5) \\
\end{array}$ & HVAC system (3.5) \\
\hline $\begin{array}{l}\text { DHW preparation system type and } \\
\text { efficiency }\end{array}$ & $\begin{array}{c}\text { Natural gas heater } \\
(0.75)\end{array}$ & $\begin{array}{c}\text { Solar thermal } \\
\text { collectors and } \\
\text { natural gas heater } \\
(0.75)\end{array}$ & $\begin{array}{c}\text { Solar thermal } \\
\text { collectors and new } \\
\text { natural gas heater } \\
(0.87)\end{array}$ & $\begin{array}{c}\text { Solar thermal } \\
\text { collectors and new } \\
\text { natural gas heater } \\
(0.87)\end{array}$ \\
\hline $\begin{array}{l}\text { Renewable energy sources } \\
\text { Solar collectors for DHW, } \mathrm{m}^{2}\end{array}$ & - & - & 80 & 80 \\
\hline Solar panels for electricity production, $\mathrm{m}^{2}$ & - & - & 0 & 135 \\
\hline
\end{tabular}

\section{4 - Presentation and Analysis of Results}

\section{1 - Energy performance}

The energy needs were calculated by simulation taking into account heating, cooling and domestic hot water production following the methodology of the Portuguese thermal regulation. The systems taken into account in this scenario for assessing the energy needs and their efficiency are presented on Table 5 . In all the renovation scenarios only natural ventilation was considered (the air changes per hour are listed on Table 5). The results of the energy simulations made for the four different scenarios are presented in Table 6.

Before renovation, the net energy for heating is $57.3 \mathrm{kWh} /\left(\mathrm{m}^{2}\right.$.year), for cooling 2.2 $\mathrm{kWh} /\left(\mathrm{m}^{2}\right.$.year) and for DHW preparation is $29.3 \mathrm{kWh} /\left(\mathrm{m}^{2}\right.$.year). In this scenario, an electrical resistance assures the heating needs, a conventional HVAC system is used for cooling and there is only natural ventilation.

In the basic renovation, the net energy for heating is $37.1 \mathrm{kWh} /\left(\mathrm{m}^{2}\right.$.year $)$, for cooling 2.8 $\mathrm{kWh} /\left(\mathrm{m}^{2}\right.$.year) and for $\mathrm{DHW}$ preparation is $29.3 \mathrm{kWh} /\left(\mathrm{m}^{2}\right.$.year $)$. An electrical resistance 
assures heating and there is only natural ventilation $(0.79$ ach, achieved due to the replacement of the windows). The installation of solar thermal collectors for DHW preparation is mandatory, since 2006, according to the Portuguese thermal regulation and therefore was considered in the nZEB and ZEB renovation scenarios.

Table 6 - Results of energy simulations for the different scenarios

\begin{tabular}{|c|c|c|c|c|}
\hline Properties of building & Before renovation & $\begin{array}{l}\text { After Basic } \\
\text { renovation }\end{array}$ & $\begin{array}{l}\text { After nZEB } \\
\text { renovation }\end{array}$ & $\begin{array}{l}\text { After ZEB } \\
\text { renovation }\end{array}$ \\
\hline \multicolumn{5}{|c|}{ Building's energy needs (net energy, without system losses), $\mathrm{kWh} /\left(\mathrm{m}^{2} \cdot\right.$ year) } \\
\hline Space heating & \begin{tabular}{|l|l}
57.3 & \\
\end{tabular} & 37.1 & 27.2 & 27.2 \\
\hline Space cooling & 2.2 & 2.8 & 3.7 & 3.7 \\
\hline Domestic hot water & 29.3 & 29.3 & 29.3 & 29.3 \\
\hline \multicolumn{5}{|c|}{ Delivered energy (energy use of technical systems with systems losses) net energy, $\mathrm{kWh} /\left(\mathrm{m}^{2} \cdot\right.$ year) } \\
\hline Space heating & \begin{tabular}{|l|}
57.3 \\
\end{tabular} & 37.1 & 6.6 & 6.6 \\
\hline Space cooling & 0.6 & 0.8 & 1.1 & 1.1 \\
\hline Domestic hot water & \begin{tabular}{|l|l}
39.1 & \\
\end{tabular} & 33.7 & 33.7 & 33.7 \\
\hline \multicolumn{5}{|c|}{ Produced energy on site, $\mathrm{kWh} /\left(\mathrm{m}^{2} \cdot\right.$ year $)$} \\
\hline Solar collectors (heat) & \begin{tabular}{|l|l|}
0 & \\
\end{tabular} & 19.4 & 27.5 & 27.5 \\
\hline PV panels (electricity) & \begin{tabular}{|l|l}
0 &
\end{tabular} & 0 & 0 & 14.3 \\
\hline \multicolumn{5}{|c|}{ Primary energy use, $\mathrm{kWh} / \mathrm{f} /\left(\mathrm{m}^{2} \cdot\right.$ year $)$} \\
\hline Energy performance value, $\mathrm{kWh}_{\mathrm{PE}} /\left(\mathrm{m}^{2}\right.$-year) & 184.0 & 125.4 & 48.4 & 0.0 \\
\hline
\end{tabular}

In the nZEB renovation, the net energy for heating is $27.2 \mathrm{kWh} /\left(\mathrm{m}^{2} \cdot\right.$ year $)$, for cooling 3.7 $\mathrm{kWh} /\left(\mathrm{m}^{2}\right.$.year) and for DHW $29.3 \mathrm{kWh} /\left(\mathrm{m}^{2}\right.$.year $)$. There is only natural ventilation $(0.55$ ach in winter and 0.60 ach in summer, achieved due to the replacement of the windows and the installation of auto-regulated ventilation grids).

The ZEB renovation scenario is the same as the $\mathrm{ZZEB}$ renovation scenario in what concerns the envelope and systems (including DHW) with the installation of PV panels to overcome the remaining building's energy needs. The considered system has around $24 \mathrm{kWp}$ and uses polycrystalline silicon (poly-Si) PV panels.

From the analysis of Table 6 it is possible to verify that compared to existing building the reduction in the primary energy consumption is around $32 \%, 74 \%$ and $100 \%$ respectively for the basic, nZEB and ZEB renovation. The reduction in the primary energy consumption of the nZEB renovation compared to the basic renovation scenario is around $61 \%$. In the ZEB scenario the building has a positive balance of $0.4 \mathrm{kWh} /\left(\mathrm{m}^{2}\right.$.year) in the delivered energy.

The investment costs of the renovation (envelope and systems) and of the replacement of the systems at the end of their lifetime ( 20 for all the systems but the PV system that is 25 years) are high (Table 4). Therefore, it is important to analyse, for each renovation scenario, the evolution of these costs along the considered lifetime (Figure 3).

Figure 3 presents the lifetime cumulative costs of each renovation scenario. The costs consider the initial cost (of renovation and systems, including materials and workmanship), maintenance of building's elements and systems, replacement of systems and operation costs of each renovation scenario. The costs of the before renovation scenario correspond to maintenance costs and the replacement of the existing radiators and fan coils for equivalent elements.

As Figure 3 shows, the Basic renovation has the shorter payback time, about 13.5 years. nZEB and ZEB renovation scenarios payback time is around 14 years, approximately half of the lifetime of the systems installed.

From the analysis of Figure 3 it is possible to understand that the contribution of renovation works and systems acquisition (year 0 ) in the overall lifetime impacts is considerable, as well as the replacement of the systems (years 20 and 25), especially in nZEB and ZEB renovation. It is also possible to see the reduced effect of the PV system cost in the ZEB renovation scenario when compared with the nZEB scenario. 


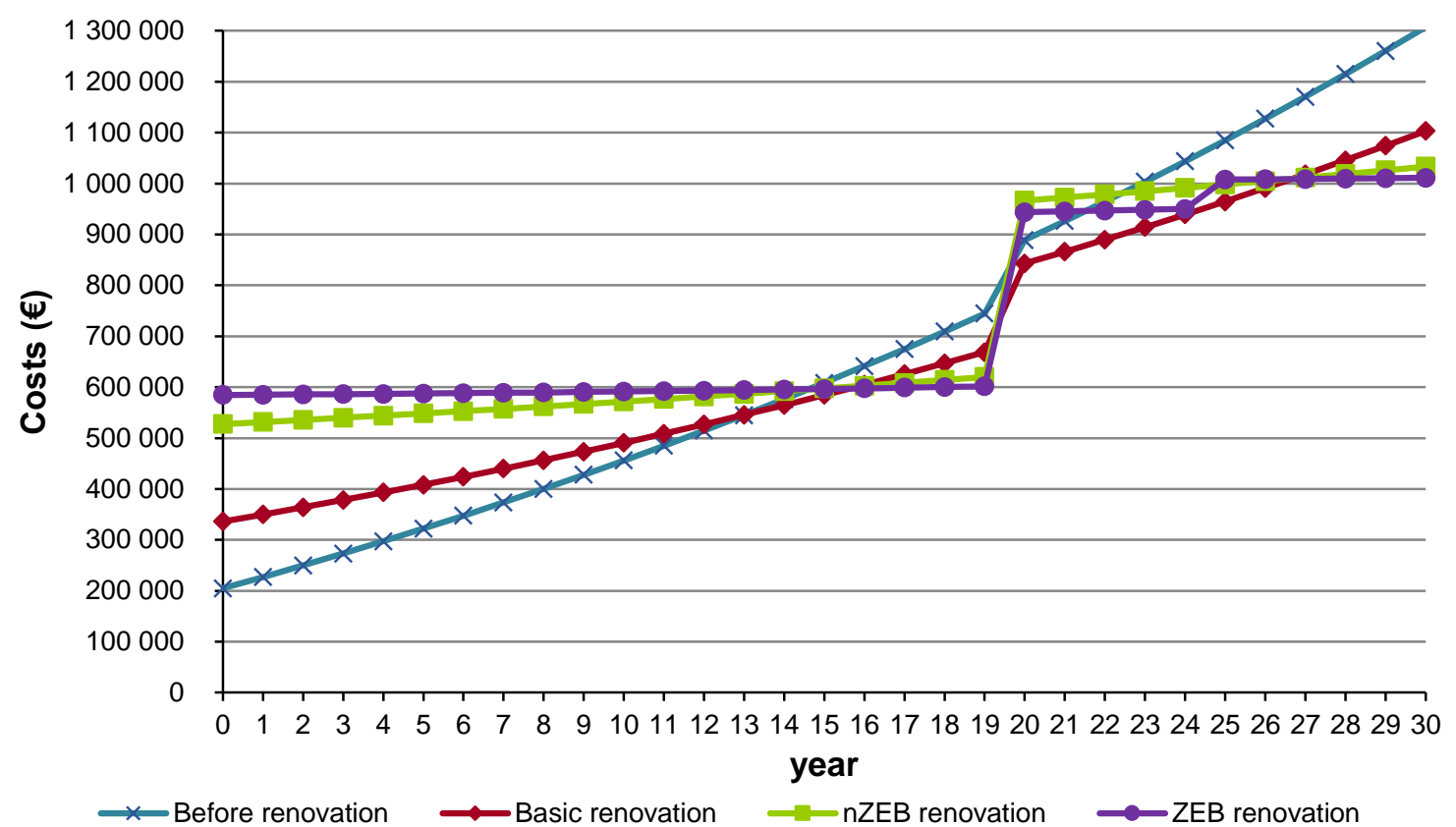

Figure 3 - Lifetime cumulative energy costs of each renovation scenario

Table 7 lists the differences in the cumulative investment costs and lifetime costs over the 30 years of the building lifetime after renovation (considering the investment costs, maintenance and operation costs).

Table 7 - Differences in the cumulative cost for the different scenarios

\begin{tabular}{|l|c|c|c|}
\hline \multirow{2}{*}{ Renovation scenario } & \multicolumn{2}{|c|}{ Investment costs } \\
\cline { 2 - 4 } & $\begin{array}{c}\text { Before } \\
\text { renovation/maintenance }\end{array}$ & After Basic renovation & After nZEB renovation \\
\hline After Basic renovation & $39 \%$ higher & - & - \\
\hline After nZEB renovation & $61 \%$ higher & $36 \%$ higher & $10 \%$ higher \\
\hline After ZEB renovation & $65 \%$ higher & $43 \%$ higher & - \\
\hline \multicolumn{2}{|c|}{ Lifetime costs } & - \\
\hline After Basic renovation & $18 \%$ lower & $7 \%$ lower & $2 \%$ lower \\
\hline After nZEB renovation & $27 \%$ lower & $26 \%$ lower & \\
\hline After ZEB renovation & $29 \%$ lower & &
\end{tabular}

These results (Table 7) show that considering the lifetime costs, the nZEB and ZEB renovations are cost effective and that the acquisition and the replacement of the HVAC systems, STC and PV systems and gas heater are both amortized before the 30 years of the renovation lifetime.

Additionally, as in the ZEB renovation the PV system was defined to cover the energy that is necessary for DHW production that is not covered by the solar thermal system and as the gas price is lower than the electricity price, the ZEB building has a positive balance in the energy bill.

Figures 4 and 5 show the cumulative energy savings and the economic payback time (EPBT) of each solar system (STC and PV), for a lifetime period of 20 years, of the different renovation scenarios, considering the uses of natural gas and electricity for DHW production

If the energy vector for the production of DHW is natural gas (Figure 4), the EPBT of the solar thermal system is bounded 4 to 5 years for the different renovation scenarios. The PV system payback time is about 12 years (less than half of its lifetime). 


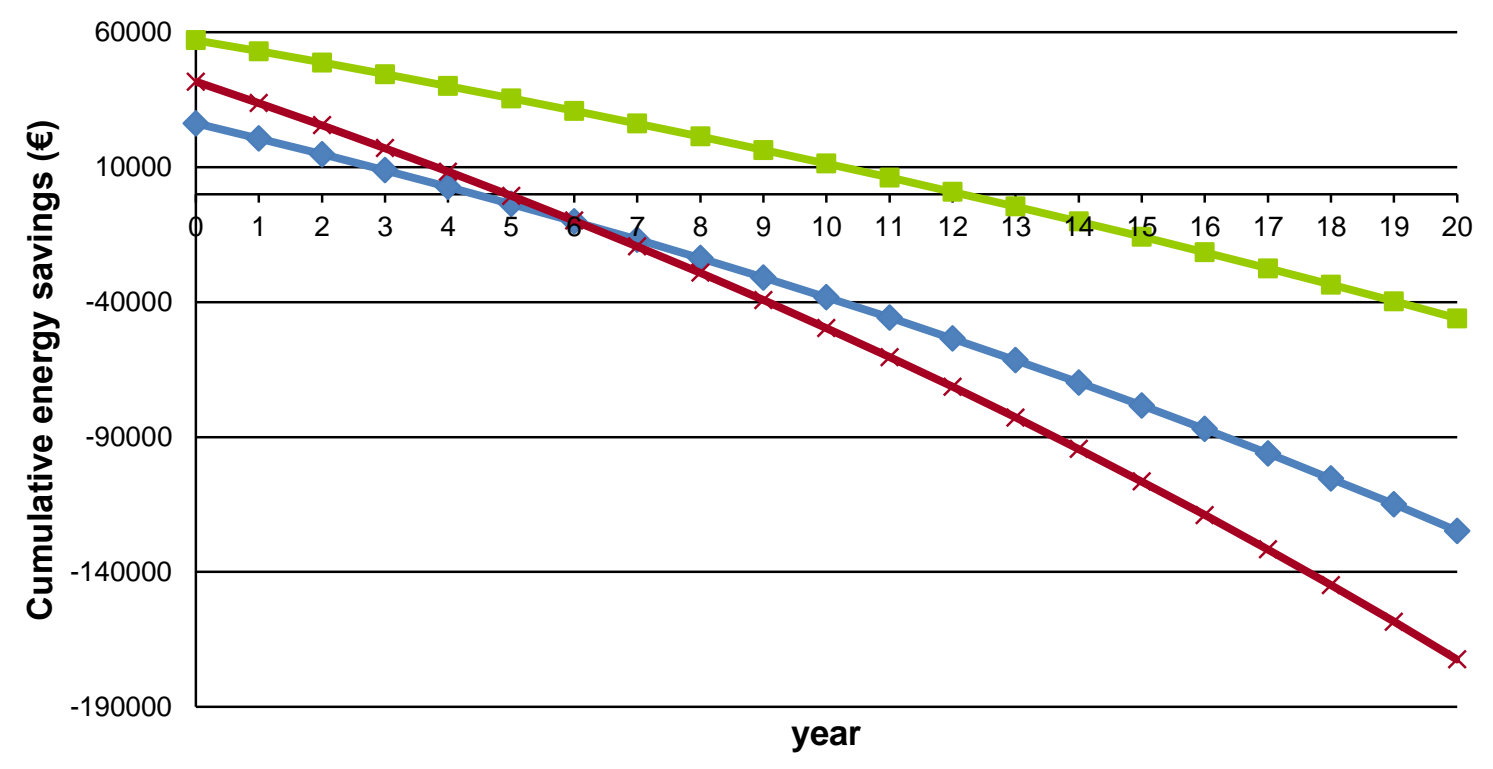

$\longrightarrow$ STC used in Basic renovation $\ldots$ STC used in nZEB and ZEB renovation - PV used in ZEB renovation

Figure 4 - Cumulative energy savings of each solar system used for a lifetime period of 20 years - natural gas for DHW production

If electricity is used to produce DHW (Figure 5), the EPBT of the solar thermal system is about 12 years for the system used for the basic renovation and 14 years for the system used in the nZEB and ZEB renovation. The EPBT in this case is substantially higher than the previous one due to the lower prices of the natural gas when compared with electricity.

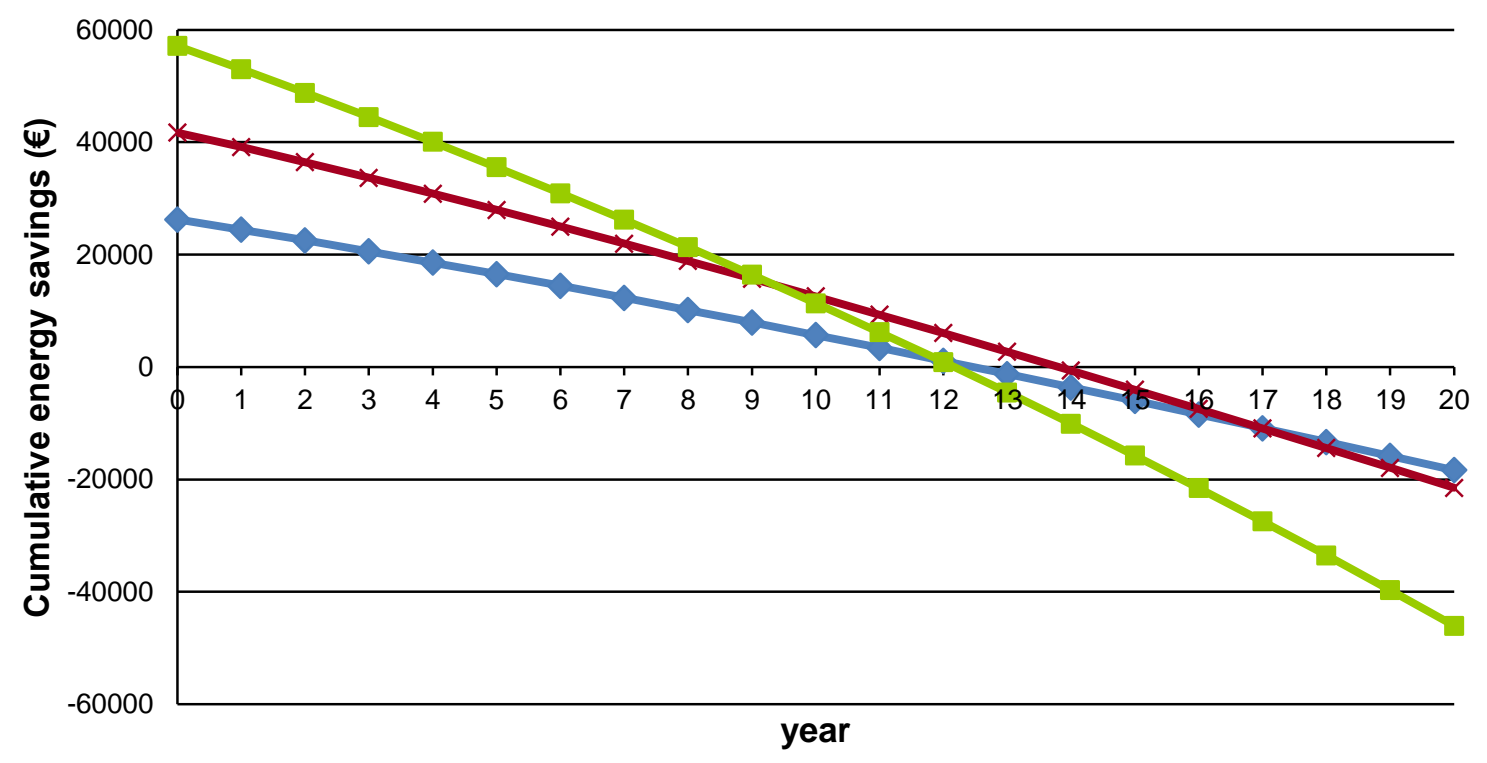

$\longrightarrow$ STC used in Basic renovation $\ldots$ STC used in nZEB and ZEB renovation $\quad$ PV used in ZEB renovation

Figure 5 - Cumulative energy savings of each solar system used for a lifetime period of 20 years - use of electricity for DHW production 


\section{2 - Environmental performance}

Table 8 presents, for each renovation scenario, the building products inputs related with the construction works of each renovation scenario.

Table 8 - Inventory of used building products

\begin{tabular}{|c|c|c|c|c|}
\hline Inventory item & \begin{tabular}{|c|} 
Before \\
renovation/maintenance
\end{tabular} & Basic renovation & nZEB renovation & ZEB renovation \\
\hline \multicolumn{5}{|c|}{ Lifetime material input $(\mathrm{kg})$} \\
\hline Water-based paint & 1278.20 & 1278.20 & 1278.20 & 1278.20 \\
\hline Synthetic mortar & & 7101.10 & 7101.10 & 7101.10 \\
\hline Expanded polystyrene (EPS) & & 757.80 & 1486.34 & 1486.34 \\
\hline Mineral wool (MW) & & 852.00 & 1533.60 & 1533.60 \\
\hline Aluminium window sills & & 260.70 & 287.70 & 287.70 \\
\hline \multicolumn{5}{|c|}{ Lifetime windows renovation $\left(m^{2}\right)$} \\
\hline Aluminium windows with double glazed glass & & 96.03 & & \\
\hline PVC windows with double glazed glass & & & 96.03 & 96.03 \\
\hline
\end{tabular}

Table 9 presents for each renovation scenario the annual equivalent lifecycle impacts (for the 30 years' life-time) and the potential improvements compared with the performance of the existing building. In the assessment of the performance of the existing building only the maintenance related impacts are considered. As recommend by the EN 15978 [28], for the ZEB scenario, Table 9 presents separately the benefits resulting from the electricity produced in the PV panels as "benefits outside the system boundary". Reasoning for this is that PV panels are connected with the public electricity network and $100 \%$ of the produced renewable electricity is exported to this network. Nevertheless, these benefits are deducted from the lifetime inside boundary's impacts in order to allow comparisons with the other scenarios. Table 10 presents the potential environmental performance improvement of each scenario.

Table 9 - Annual equivalent life-cycle impacts per net floor area and potential improvements resulting from each renovation scenario

\begin{tabular}{|c|c|c|c|c|c|c|c|c|c|}
\hline \multirow[b]{2}{*}{$\begin{array}{l}\text { Environme } \\
\text { ntal } \\
\text { indicator }\end{array}$} & \multirow{2}{*}{$\begin{array}{l}\begin{array}{l}\text { Before } \\
\text { renovation }\end{array} \\
\text { Impacts } \\
\text { (/m².year) }\end{array}$} & \multicolumn{2}{|c|}{ Basic renovation } & \multicolumn{2}{|c|}{ nZEB renovation } & \multicolumn{4}{|c|}{ ZEB renovation } \\
\hline & & $\begin{array}{l}\text { Impacts } \\
\left(/ \mathrm{m}^{2} \text {.year }\right)\end{array}$ & $\begin{array}{l}\text { Improvem } \\
\text { ent (\%) }\end{array}$ & $\begin{array}{l}\text { Impacts } \\
\left(/ \mathrm{m}^{2} \text {.year }\right)\end{array}$ & $\begin{array}{l}\text { Improvemen } \\
\mathrm{t}(\%)\end{array}$ & $\begin{array}{l}\text { Impacts of } \\
\text { the } \\
\text { physical } \\
\text { boundaries } \\
\left(/ \mathrm{m}^{2} \text {.year }\right)\end{array}$ & $\begin{array}{l}\text { Benefits } \\
\text { outside } \\
\text { the } \\
\text { system } \\
\text { boundary }\end{array}$ & $\begin{array}{l}\text { Overall } \\
\text { impacts } \\
\left(/ \mathrm{m}^{2} \text {.year }\right)\end{array}$ & $\begin{array}{l}\text { Improve } \\
\text { ment } \\
(\%)\end{array}$ \\
\hline $\begin{array}{l}\text { ADP_elem } \\
\text { ents }\end{array}$ & 4,75E-05 & $6,20 \mathrm{E}-05$ & $-30 \%$ & $1,05 E-04$ & $-121 \%$ & 2,13E-04 & 1,08E-05 & 2,02E-04 & $-326 \%$ \\
\hline ADP_FF & $5,80 \mathrm{E}+02$ & $3,70 \mathrm{E}+02$ & $36 \%$ & $1,01 \mathrm{E}+02$ & $83 \%$ & $1,32 \mathrm{E}+02$ & $1,11 \mathrm{E}+02$ & $2,05 \mathrm{E}+01$ & $96 \%$ \\
\hline GWP100a & $4,25 \mathrm{E}+01$ & $2,80 \mathrm{E}+01$ & $34 \%$ & $7,38 \mathrm{E}+00$ & $83 \%$ & $9,88 \mathrm{E}+00$ & $8,49 \mathrm{E}+00$ & $1,86 \mathrm{E}+00$ & $96 \%$ \\
\hline ODP & $2,95 \mathrm{E}-06$ & $2,01 \mathrm{E}-06$ & $32 \%$ & $6,07 \mathrm{E}-07$ & $79 \%$ & $1,14 \mathrm{E}-06$ & $6,10 \mathrm{E}-07$ & $5,25 \mathrm{E}-07$ & $82 \%$ \\
\hline POCP & 1,29E-02 & $9,23 E-03$ & $28 \%$ & $2,71 \mathrm{E}-03$ & $79 \%$ & $3,71 \mathrm{E}-03$ & $2,72 \mathrm{E}-03$ & $9,82 \mathrm{E}-04$ & $92 \%$ \\
\hline $\mathrm{AP}$ & $3,01 \mathrm{E}-01$ & $2,13 \mathrm{E}-01$ & $29 \%$ & 5,93E-02 & $80 \%$ & $7,92 \mathrm{E}-02$ & $6,72 \mathrm{E}-02$ & $1,20 \mathrm{E}-02$ & $96 \%$ \\
\hline EP & $7,11 \mathrm{E}-02$ & $5,35 \mathrm{E}-02$ & $25 \%$ & $1,88 \mathrm{E}-02$ & $74 \%$ & $2,90 \mathrm{E}-02$ & 1,69E-02 & $1,20 \mathrm{E}-02$ & $83 \%$ \\
\hline CED NRE & $6,18 \mathrm{E}+02$ & $3,98 \mathrm{E}+02$ & $36 \%$ & $1,11 \mathrm{E}+02$ & $82 \%$ & $1,46 \mathrm{E}+02$ & $1,20 \mathrm{E}+02$ & $2,55 \mathrm{E}+01$ & $96 \%$ \\
\hline CED_TOT & $7,19 \mathrm{E}+02$ & $4,67 \mathrm{E}+02$ & $35 \%$ & $1,27 \mathrm{E}+02$ & $82 \%$ & $1,69 \mathrm{E}+02$ & $1,45 \mathrm{E}+02$ & $3,22 \mathrm{E}+01$ & $96 \%$ \\
\hline
\end{tabular}

Table 10 - Weighted average potential environmental performance improvement $\left(E I_{i}\right)$ of each scenario

\begin{tabular}{|l|l|}
\hline Renovation scenario & Potential environmental performance improvement $\left(\mathrm{El}_{\mathrm{i}}\right)$ \\
\hline Basic & $32 \%$ \\
\hline nZEB & $80 \%$ \\
\hline ZEB & $92 \%$ \\
\hline
\end{tabular}

From the analysis of Tables 9 and 10 it is possible to conclude that the lower the energy consumption of a renovation scenario is the better is the environmental performance. As 
presented in Table 6, in average, the potential environmental performance improvement $\left(E I_{i}\right)$ is $32 \%, 80 \%$ and $92 \%$ for the Basic, nZEB and ZEB renovation scenarios, respectively. Making a sensitivity analysis to these results, by changing the weight of each considered environmental indicator, it is possible to conclude that the $\mathrm{El}$ of each renovation scenario is bounded between $25 \%$ to $36 \%, 74 \%$ to $83 \%$ and $82 \%$ to $96 \%$ in the Basic, nZEB and ZEB scenario, respectively. Since the goal of the nZEB scenario was to reduce in $80 \%$ the primary energy needs of the existing building (before renovation), results show good correlation between the reduction of energy needs and the reduction of the overall potential environmental impacts. These results also highlight that he contribution of the energy related impacts in the overall potential environmental life-cycle impacts is much higher when compared with the contribution of the building integrated energy systems and embodied impacts of building products. This means that the thermal retrofitting of building envelopes together with the integration of solar systems (STC and PV) is a good principle to significantly reduce the lifecycle impacts of a building.

In order to clearly understand the differences between the results obtained, Figure 6 presents in a radar graph and for each analysed scenario, the normalized value of each indicator. In the used normalized method, normalized values are bounded between 0 and 1 , where 0 and 1 represent, respectively, the worst and the best valued within the values of an indicator. Therefore, the closer to 1 the better the scenario is.

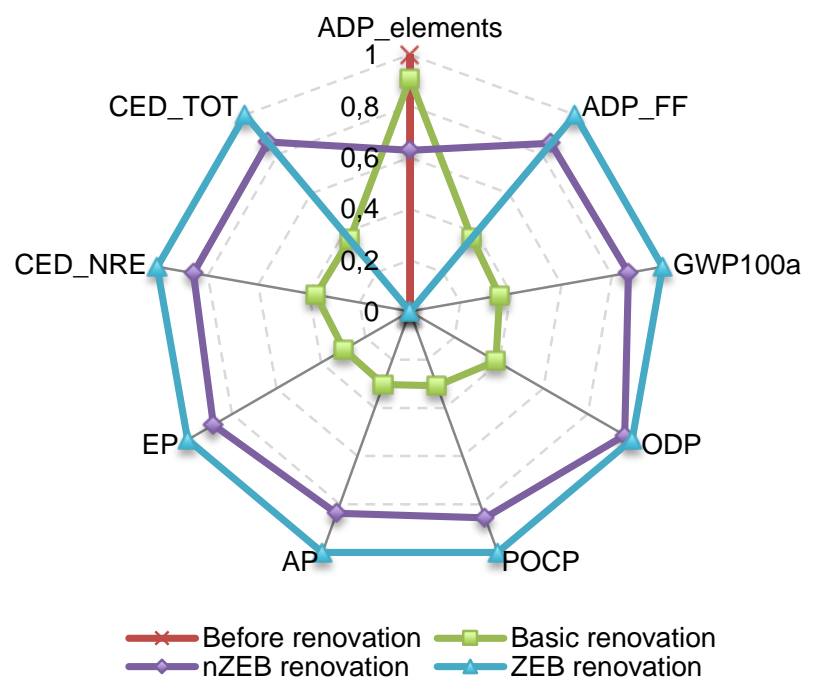

Figure 6 - Environmental profile of each renovation scenario

From the analysis of Figure 6 it is possible to conclude that the "before renovation" scenario is only better than the others at the level of the ADP_elements impact category. Analysing each renovation scenario at this impact category it is possible to say that the three processes that most contribute for it are: the electricity consumption $(46,5 \%)$, the installation of the STCs $(42,5 \%)$ and the installation of the new windows $(5,7 \%)$, in the basic renovation; the installation of the STCs $(50,2 \%)$, the installation of the new windows $(41,6 \%)$ and the electricity consumption (5,7\%), in the nZEB renovation; the installation of PVs $(50,7 \%)$, the installation of the STCs $(24,7 \%)$ and the installation of the new windows $(20,5 \%)$, in the ZEB renovation scenario. Therefore, the worst performance at this level of the renovation scenarios is related to the fact that the energy savings does not compensate the high abiotic potential of the STCs, PVs and windows.

Another aspect to highlight is the difference between the environmental profile of the before renovation/maintenance scenario and the nZEB scenario and between the last and the ZEB scenario. These differences emphasize the importance of adopting a design strategy that 
starts by improving the energy performance of the building envelope followed by the integration of solar systems (or other renewable systems) to overcome the remaining energy needs.

As presented in Table 4, the environmental impact category that most influences the overall environmental performance is the Global Warming Potential (GWP). Therefore, it is relevant to analyse, for each renovation scenario, the evolution of this impact category along the considered lifetime (Figure 7). From the analysis of Figure 7 it is possible to understand that the contribution of renovation works (Year 0 ) in the overall lifecycle impacts is very low. It is also possible to see the reduced effect of replacing the STC systems in the three renovation scenarios (year 20) and the effect of replacing the PV system in the ZEB scenario (year 25). Due to the avoided $\mathrm{CO}_{2}$ emissions related to the production of renewable electricity in the PV panels integrated in the ZEB scenario, it is possible to see the slightly decrease of the accumulated GWP along the considered lifetime. Compared with the before renovation/maintenance scenario, the emissions saved in the lifetime are 549 ton. $\mathrm{CO}_{2}$ eq., 1340 ton. $\mathrm{CO}_{2}$ eq. and 1560 ton. $\mathrm{CO}_{2}$ eq. for the Basic, nZEB and ZEB scenario, respectively. Additionally, it is possible to conclude that the Greenhouse Emissions Payback Time (GPBT) of each scenario is around 5 years, 1.5 years and 2 years for the Basic, nZEB and ZEB scenario, respectively.

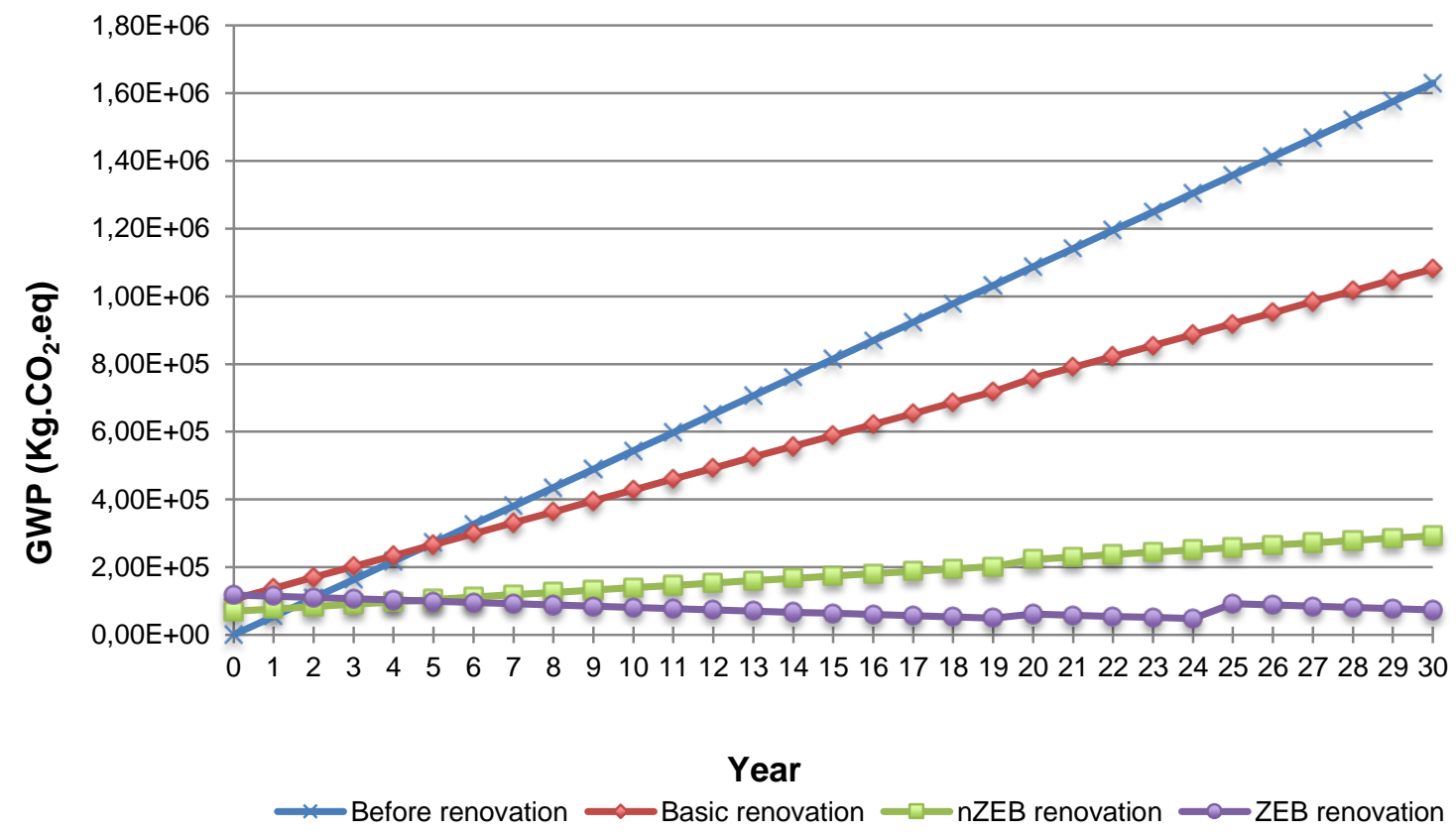

Figure 7 - Lifetime Cumulative Global Warming Potential (GWP) of each renovation scenario

Figure 8 presents the lifetime Cumulative Energy Demand (total) - CEDTот - of each renovation scenario. The CED the building products and energy systems used and the delivered energy consumed during the building operation phase and in the operation. It also includes maintenance and replacement of the building energy systems. 


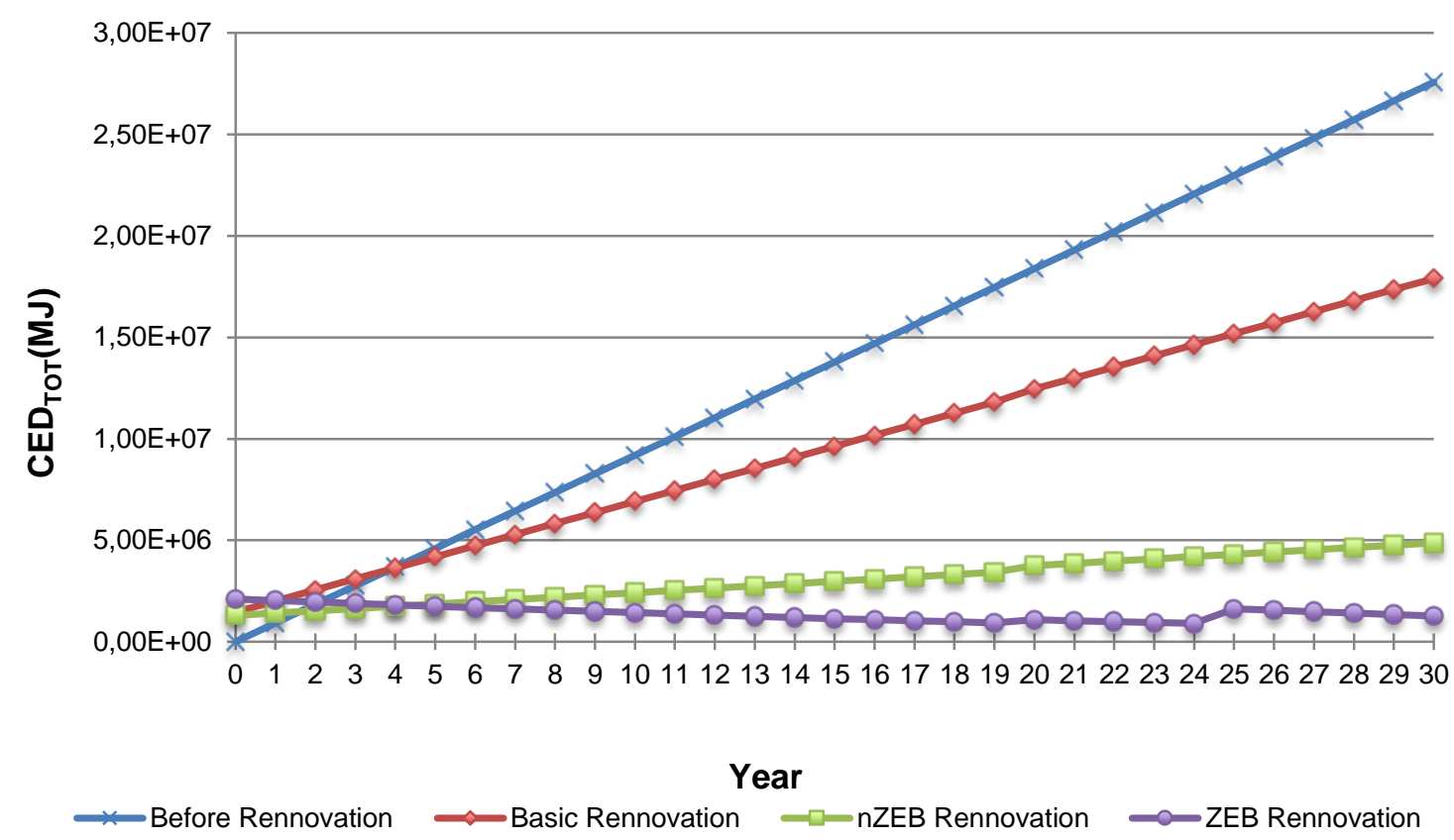

Figure 8 - Lifetime Cumulative Energy Demand (CEDтот) of each renovation scenario

Comparing Figure 8 with Figure 7, the results show good correlation with the $\mathrm{CO}_{2}$ cumulative emissions, showing the importance of the energy consumption in the potential environmental impacts. Compared with the before renovation scenario, the lifetime saved CED Tот is 9670 GJ (2 686111 kWh), 22700 GJ (6 305556 kWh) and 26300 GJ (7 305556 kWh), for the Basic, nZEB and ZEB scenarios respectively. Additionally, it is possible to conclude that the energy payback time (EPBT) of each renovation scenario is around 4 years, 1.5 years and 2 years for the Basic, nZEB and ZEB scenario, respectively.

At the level of the used energy systems (STC and PV) it is also interesting to study both the GPBT and EPBT. This is important to understand both the environmental and energy benefits of using solar systems. For this purpose, Figure 9 and 10 present, respectively, the cumulative GWP and CED тот of each used solar system for a lifetime period of 20 years.

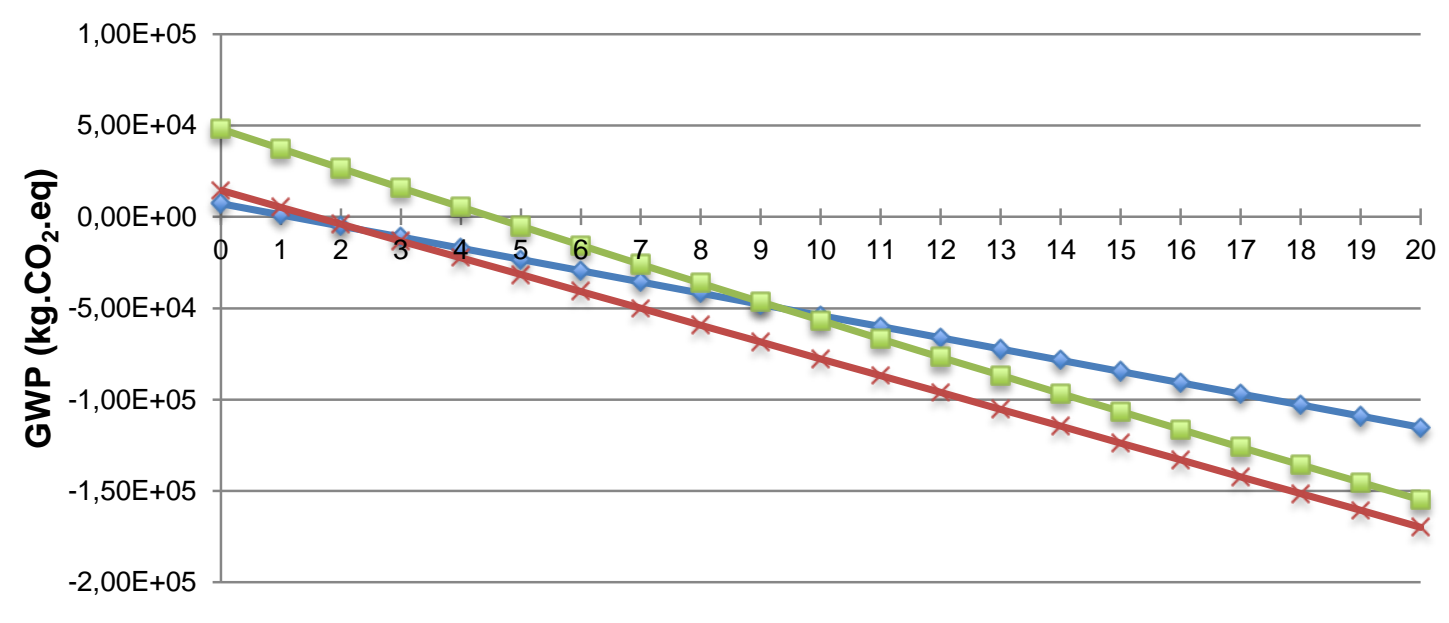

$\leadsto$ STC used in basic renovation $\leadsto$ STC used in nZEB and ZEB renovation $\square-\mathrm{PV}$ used in ZEB renovation

Years

Figure 9 - Cumulative GWP of each used solar system for a lifetime period of 20 years 


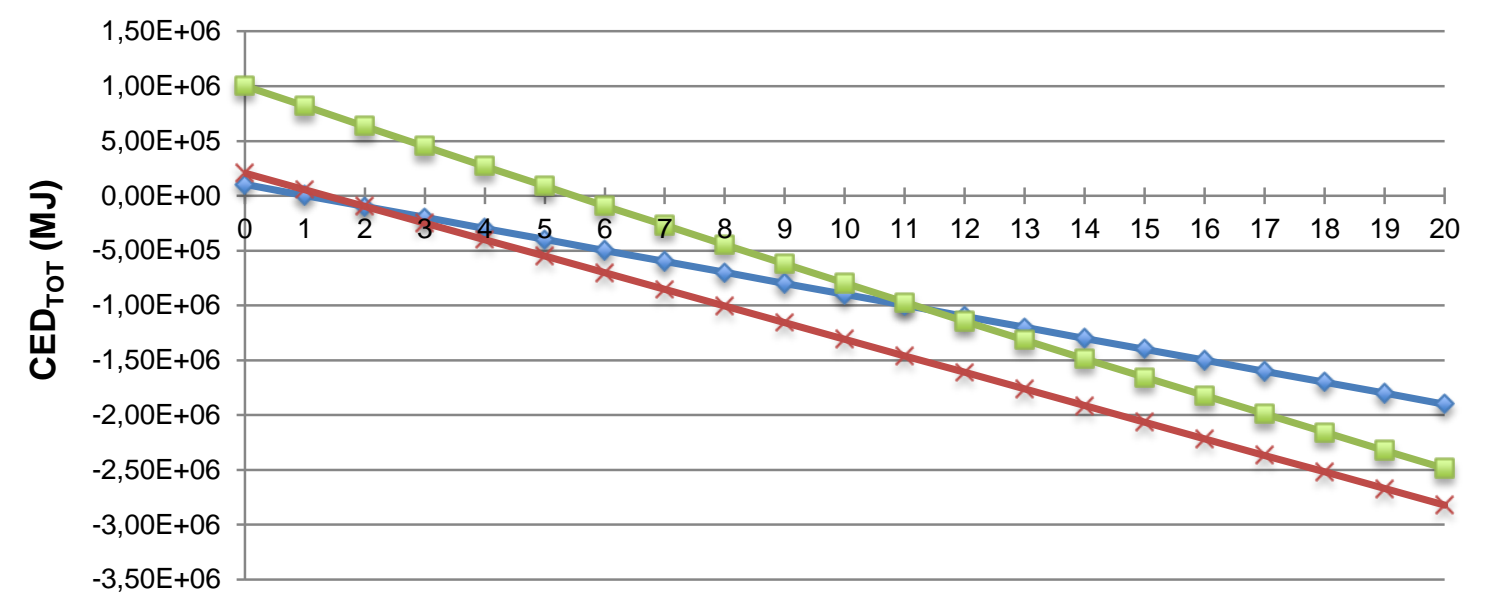

$\simeq$ STC used in basic renovation $\longleftarrow$ STC used in nZEB and ZEB renovation $\square-\mathrm{PV}$ used in ZEB renovation

\section{Years}

Figure 10 - Cumulative $\mathrm{CED}_{\text {Tот }}$ of each used solar system for a lifetime period of 20 years

The data presented for year 0 in Figures 9 and 10 represent the embodied impacts related to the production and installation of the systems. In the case of the STC systems, the annual avoided $\mathrm{CO}_{2}$ emissions and saved CED тот were assessed considering the avoided natural gas consumption in the preparation of the domestic hot water. For the PV, the avoided emissions and saved CED by the PV system is produced according to the Portuguese energy mix.

From the analysis of Figure 9 it is possible to conclude that the GPBT is around 1.17 years (14 months), 1.58 years ( 19 months) and 4.50 years (54 months) in the case of STC system used in basic renovation, STC system used in nZEB and ZEB renovation and PV system used in ZEB renovation, respectively. Regarding EPBT (Figure 10) it is possible to conclude that is around 1 year (12 months), 1.33 years (16 months) and 5.5 years (66 months) in the case of STC system used in basic renovation, STC system used in nZEB and ZEB renovation and PV system used in ZEB renovation, respectively. Regarding the results obtained for the STCs they are in line with the results of other international studies. For example, Kalogirou [51] investigated a domestic, thermosiphon solar water heater (for the climate conditions of Nicosia, Cyprus) and concluded that the energy spent for manufacture/installation was recouped in approximately 13 months. At the level of PVs, for example, Lu [52] studied the sustainability of a roof-mounted $22 \mathrm{~kW}$ building integrated PV system in Hong Kong and concluded a GPBT ranging from 3.6 to 5.3 years (depending on the considered energy mix) and a EPBT of 7.3 years.

\section{Conclusions}

This paper studied four renovation scenarios (maintenance, basic, nZEB and ZEB) for a multifamily building located in the suburbs of Porto, Portugal. The building is representative of $41 \%$ of the Portuguese residential building stock and represents the buildings built between 1990 and 2000.

For each renovation scenario the economic payback time and greenhouse emissions payback time for the materials and systems used were assessed. To study the efficiency of each renovation scenario this paper calculated the lifetime costs and energy consumption using the Portuguese thermal regulation methodology. Additionally, the payback time of the renewable energy systems was also estimated. 
The basic renovation (minimum requirements to fulfil the national thermal regulation) allows a $32 \%$ reduction in the annual energy needs and the nZEB renovation allows a $73 \%$ reduction in the annual energy needs compared with the maintenance scenario. The main differences in the renovation costs of each scenario are due to the systems considered (HVAC, solar thermal and PV).

Even with a $65 \%$ increase in the renovation costs (investment, maintenance and operation) compared with the maintenance costs, the ZEB renovation has the lowest lifetime costs, $29 \%$ lower than the maintenance scenario (and $26 \%$ lower than the basic renovation scenario). The ZEB renovation investment costs are $10 \%$ higher than the ones of the nZEB renovation, leading to $2 \%$ reduction in the energy lifetime costs.

The costs of the nZEB renovation are $61 \%$ higher than the maintenance costs and $36 \%$ higher than the basic renovation scenario costs. The energy lifetime costs are $27 \%$ lower than the maintenance costs and 7\% lower than the basic renovation scenario.

These results show that considering the lifetime costs, the nZEB and ZEB renovation are cost effective and that even the replacement of the HVAC systems and of the solar thermal system after 20 years and of the PV systems after 25 years, the costs are amortized before the 30 years of the renovation lifetime.

Additionally, as in the ZEB renovation scenario the PV system was defined to produce the energy for DHW not supplied by the solar thermal system, and as the natural gas price is lower than the electricity price, the ZEB building has a positive balance in the energy bill.

The potential environmental performance improvement (Eli) of the Basic, nZEB and ZEB renovation scenarios is respectively $32 \%, 80 \%$ and $92 \%$, showing a good correlation between the reduction of energy needs and the reduction of the overall potential environmental impacts. The analyses also highlight that the contribution of the energy related impacts in the overall potential environmental life-cycle impacts is much higher when compared with the contribution of the energy systems and of the embodied impacts of the building products. This study also shows that a great amount of energy and carbon emissions are avoided for every renovation scenario during the considered lifetime (30 years) and that the $\mathrm{nZEB}$ and ZEB scenarios are financially feasible, with payback times inside the considered lifetime for the renovated building.

The economic payback time (EPBT) of each renovation scenario is about 4 years, 1.5 years and 2 years for the Basic, nZEB and ZEB scenario, respectively. The greenhouse emissions payback time (GPBT) of each scenario is about 5 years, 1.5 years and 2 years for the Basic, nZEB and ZEB scenario, respectively. For the renewable energy systems, the GPBT is about 1.17 years 1.58 years and 4.50 in the case of STC systems used in basic renovation, STC systems used in nZEB and ZEB renovation and PV systems used in ZEB renovation, respectively. The EPBT is about 1 year, 1.33 years and 5.5 years in the case of STC systems used in basic renovation, STC systems used in nZEB and ZEB renovation and PV systems used in ZEB renovation, respectively.

In conclusion, this study shows that the considered scenarios for the implementation of the nZEB and ZEB energy levels in Portuguese multifamily buildings are cost effective while providing important potential environmental benefits during the lifetime of a renovation scenario (30 years). The energy prices variation and the discount rate might change the results of the analysis and in some situations the use of solar thermal and PV systems might not be adequate due to the shading of the surrounding buildings or an insufficient area to install the solar thermal and PV panels. In this situation an alternative renewable energy source should be considered, depending on the location of the building.

\section{Acknowledgements}

This research was supported by the IEE Project SouthZEB (under the reference IEE/13/393) and by the Portuguese Foundation for Science and Technology (FCT) in the framework of the Strategic Projects UID/ECI/04047/2013 and UID/FIS/04650/2013. 


\section{References}

[1] EPBD recast, EU-Directive 2010/31/EU of the European Parliament and of the Council of 19 May 2010 on the energy performance of buildings, 2010.

[2] T. Boermans, A. Hermelink, S. Schimschar, J. Grözinger, M. Offermann, K.E. Thomsen, et al., Principles for Nearly Zero-Energy Buildings - Paving the way to effective implementation of policy requirements, 2011.

http://www.bpie.eu/documents/BPIE/publications/LR_nZEB study.pdf (accessed December 4, 2015).

[3] M. Ferreira, M. Almeida, A. Rodrigues, Cost optimality and net-zero energy in the renovation of Portuguese residential building stock - Rainha Dona Leonor neighbourhood case study, Int. J. Sustain. Build. Technol. Urban Dev. 5 (2014) 306317. doi:10.1080/2093761X.2014.979268.

[4] E. Comission, 2030 climate and energy goals for a competitive, secure and lowcarbon EU economy, (n.d.). http://europa.eu/rapid/press-release_IP-14-54_en.htm (accessed December 5, 2015).

[5] E. Comission, A policy framework for climate and energy in the period from 2020 to 2030 - Communication from the Commission to the European Parliament, the Council, the European Economic and Social Committee and the Committee of the Regions, (n.d.).

[6] E. Comission, Directive 2009/28/EC of the European Parliament and of the Council on the promotion of the use of energy from renewable sources and amending and subsequently repealing Directives 2001/77/EC and 2003/30/EC., Off. J. Eur. Union L 140. (2009) 16-47.

[7] M. Ferreira, M. Almeida, A. Rodrigues, S.M. Silva, Comparing cost-optimal and netzero energy targets in building retrofit, Build. Res. Inf. (2014) 1-14. doi:10.1080/09613218.2014.975412.

[8] M. Almeida, A. Rodrigues, I. Cabral, M. Ferreira, A. Coehlo, G. Machado, Deep energy retrofit of vernacular housing, Rehva Eur. HVAC J. (2014). http://eprints.sparaochbevara.se/811/ (accessed December 4, 2015).

[9] E. Comission, $\operatorname{COM(2011)~} 112$ final. A Roadmap for moving to a competitive low carbon economy in 2050 - Communication From the Commission to the European Parliament, the Council, the European Economic and Social Committee and the committee of the regions, (n.d.).

[10] F. Bartiaux, K. Gram-Hanssen, P. Fonseca, L. Ozolina, T.H. Christensen, A practicetheory approach to homeowners' energy retrofits in four European areas, Build. Res. Inf. 42 (2014) 525-538. doi:10.1080/09613218.2014.900253.

[11] G. Gorgolis, D. Karamanis, Solar energy materials for glazing technologies, Sol. Energy Mater. Sol. Cells. 144 (2016) 559-578. doi:10.1016/j.solmat.2015.09.040.

[12] V.V. Tyagi, N.A.A. Rahim, N.A. Rahim, J.A. /L. Selvaraj, Progress in solar PV technology: Research and achievement, Renew. Sustain. Energy Rev. 20 (2013) 443461. doi:10.1016/j.rser.2012.09.028.

[13] G.K. Singh, Solar power generation by PV (photovoltaic) technology: A review, Energy. 53 (2013) 1-13. doi:10.1016/j.energy.2013.02.057.

[14] A. Badea, T. Baracu, C. Dinca, D. Tutica, R. Grigore, M. Anastasiu, A life-cycle cost analysis of the passive house "POLITEHNICA" from Bucharest, Energy Build. 80 (2014) 542-555. doi:10.1016/j.enbuild.2014.04.044.

[15] C. Lamnatou, D. Chemisana, R. Mateus, M.G. Almeida, S.M. Silva, Review and perspectives on Life Cycle Analysis of solar technologies with emphasis on buildingintegrated solar thermal systems, Renew. Energy. 75 (2015) 833-846. doi:10.1016/j.renene.2014.09.057.

[16] A. Zahedi, Maximizing solar PV energy penetration using energy storage technology, Renew. Sustain. Energy Rev. 15 (2011) 866-870. doi:10.1016/j.rser.2010.09.011. 
[17] S.A. Kalogirou, Y. Tripanagnostopoulos, Hybrid PV/T solar systems for domestic hot water and electricity production, Energy Convers. Manag. 47 (2006) 3368-3382. doi:10.1016/j.enconman.2006.01.012.

[18] R. Mateus, L. Bragança, Sustainability assessment and rating of buildings: Developing the methodology SBToolPT-H, Build. Environ. 46 (2011) 1962-1971. doi:10.1016/j.buildenv.2011.04.023.

[19] G.L. Tiago Filho, C.A. Rosa, R.M. Barros, I.F.S. Dos Santos, F. das G.B. da Silva, Study of the energy balance and environmental liabilities associated with the manufacture of crystalline Si photovoltaic modules and deployment in different regions, Sol. Energy Mater. Sol. Cells. 144 (2016) 383-394. doi:10.1016/j.solmat.2015.09.023.

[20] M. Morelli, L. Rønby, S.E. Mikkelsen, M.G. Minzari, T. Kildemoes, H.M. Tommerup, Energy retrofitting of a typical old Danish multi-family building to a "nearly-zero" energy building based on experiences from a test apartment, Energy Build. 54 (2012) 395406. doi:10.1016/j.enbuild.2012.07.046.

[21] W. Ott, R. Bolliger, V. Ritter, S. Citherlet, D. Favre, B. Perriset, et al., Methodology for Cost-Effective Energy and Carbon Emissions Optimization in Building Renovation (Annex 56), Guimarães, 2014. http://www.ieaannex56.org/Groups/GroupltemID6/STA_methods_impacts_report.pdf (accessed December 4, 2015).

[22] D. INE, Inquérito ao Consumo de Energia no Sector Doméstico 2010, INE, DGEG, Lisbon, 2011.

[23] Portugal, Regulamento de Desempenho Energético dos Edifícios de Habitação [Portuguese Thermal Regulation]. Decreto-Lei no 118/2013 de 20 de Agosto, Portugal, 2013., n.d.

[24] I.\& LNEC, Parque Habitacional e a sua Reabilitação - Análise e Evolução., (2013). http://www.ine.pt/xportal/xmain?xpid=INE\&xpgid=ine_publicacoes\&PUBLICACOESpu b_boui $=165231362 \&$ PUBLICACOEStema $=00 \&$ PUBLICACOESmodo $=2$.

[25] CEN, EN 15804:2012. Sustainability of construction works - Environmental product declarations - Core rules for the product category of construction products, 2012.

[26] ISO, ISO 13790:2008 - Energy performance of buildings -- Calculation of energy use for space heating and cooling, Geneva, 2008.

http://www.iso.org/iso/home/store/catalogue_tc/catalogue_detail.htm?csnumber=4197 4 (accessed December 5, 2015).

[27] EC 2012/C 115/01, Guidelines accompanying Commission Delegated Regulation (EU) No 244/2012 of 16 January 2012 supplementing Directive 2010/31/EU of the European Parliament and of the Council on the energy performance of buildings by establishing a comparative methodology f, Off. J. Eur. Union. (2012) 28.

[28] CEN, EN 15978:2011. Sustainability of construction works. Assessment of environmental performance of buildings. Calculation method, 2011.

[29] ISO, ISO 14040:2006 Environmental management - Life cycle assessment - Principles and framework, Geneva, 2006.

http://www.iso.org/iso/catalogue_detail?csnumber=37456.

[30] Pré-consultants, SimaPro Database Manual - Methods Library, Product Ecology Consultants, Amersfoort, 2008.

[31] B.P. Weidema, C. Bauer, R. Hischier, C. Mutel, T. Nemecek, J. Reinhard, et al., Overview and methodology. Data quality guideline for the ecoinvent database version 3, St. Gallen, 2013.

http://www.ecoinvent.org/files/dataqualityguideline_ecoinvent_3_20130506.pdf.

[32] Gabi, Gabi LCA Databases, (2015). http://www.gabi-software.com/databases/gabidatabases/.

[33] N. Pargana, M.D. Pinheiro, J.D. Silvestre, J. de Brito, Comparative environmental life cycle assessment of thermal insulation materials of buildings, Energy Build. 82 (2014) 466-481. doi:10.1016/j.enbuild.2014.05.057. 
[34] D.C. Jordan, S.R. Kurtz, Photovoltaic Degradation Rates-an Analytical Review, Prog. Photovoltaics Res. Appl. 21 (2013) 12-29. doi:10.1002/pip.1182.

[35] A.F. Abd Rashid, S. Yusoff, A review of life cycle assessment method for building industry, Renew. Sustain. Energy Rev. 45 (2015) 244-248.

doi:10.1016/j.rser.2015.01.043.

[36] R. Mateus, S. Neiva, L. Bragança, P. Mendonça, M. Macieira, Sustainability assessment of an innovative lightweight building technology for partition walls Comparison with conventional technologies, Build. Environ. 67 (2013) 147-159. doi:10.1016/j.buildenv.2013.05.012.

[37] C. Lamnatou, G. Notton, D. Chemisana, C. Cristofari, The environmental performance of a building-integrated solar thermal collector, based on multiple approaches and lifecycle impact assessment methodologies, Build. Environ. 87 (2015) 45-58. doi:10.1016/j.buildenv.2015.01.011.

[38] L. Belussi, M. Mariotto, I. Meroni, C. Zevi, S.D. Svaldi, LCA study and testing of a photovoltaic ceramic tile prototype, Renew. Energy. 74 (2015) 263-270. doi:10.1016/j.renene.2014.07.053.

[39] O. Ortiz, F. Castells, G. Sonnemann, Sustainability in the construction industry: A review of recent developments based on LCA, Constr. Build. Mater. 23 (2009) 28-39. doi:10.1016/j.conbuildmat.2007.11.012.

[40] M.M. Khasreen, P.F.G. Banfill, G.F. Menzies, Life-Cycle Assessment and the Environmental Impact of Buildings: A Review, Sustainability. 1 (2009) 674-701. doi:10.3390/su1030674.

[41] R. Frischknecht, N. Jungbluth, H.-J. Althaus, C. Bauer, G. Doka, R. Dones, et al., Swiss Centre for Life Cycle Inventories Implementation of Life Cycle Impact Assessment Methods, 2007.

[42] H. Monteiro, F. Freire, Life-cycle assessment of a house with alternative exterior walls: Comparison of three impact assessment methods, Energy Build. 47 (2012) 572-583. doi:10.1016/j.enbuild.2011.12.032.

[43] H.M. dos S. Gervásio, Sustainable design and integral life-cycle analysis of bridges, University of Coimbra, Faculty of Ciences and Technology, 2010. http://hdl.handle.net/10316/14577 (accessed April 14, 2016).

[44] T. Rogmans, M. Ghunaim, A framework for evaluating sustainability indicators in the real estate industry, Ecol. Indic. 66 (2016) 603-611. doi:10.1016/j.ecolind.2016.01.058.

[45] G.E. Marjaba, S.E. Chidiac, Sustainability and resiliency metrics for buildings - Critical review, Build. Environ. 101 (2016) 116-125. doi:10.1016/j.buildenv.2016.03.002.

[46] A. Haapio, P. Viitaniemi, A critical review of building environmental assessment tools, Environ. Impact Assess. Rev. 28 (2008) 469-482. doi:10.1016/j.eiar.2008.01.002.

[47] F. Asdrubali, G. Baldinelli, F. Bianchi, S. Sambuco, A comparison between environmental sustainability rating systems LEED and ITACA for residential buildings, Build. Environ. 86 (2015) 98-108. doi:10.1016/j.buildenv.2015.01.001.

[48] R. Mateus, L. Bragança, Tecnologias Construtivas para a Sustentabilidade da Construção (in english: Building Technologies for Sustainable Construction), Ecopy, Ermesinde, 2006.

[49] EPA Science Advisory Board, Towards an Integrated Environmental Decision-Making, Washigton, DC, 2000.

[50] E. and SBA, Reducing Risk: Setting Priorities and Strategies for Environmental Protection, Washington, DC, 2000.

[51] S. Kalogirou, Thermal performance, economic and environmental life cycle analysis of thermosiphon solar water heaters, Sol. Energy. 83 (2009) 39-48. doi:10.1016/j.solener.2008.06.005.

[52] L. Lu, H.X. Yang, Environmental payback time analysis of a roof-mounted buildingintegrated photovoltaic (BIPV) system in Hong Kong, Appl. Energy. 87 (2010) 36253631. doi:10.1016/j.apenergy.2010.06.011. 